\title{
Molecular Phylogeny and Morphology of Amphisphaeria (= Lepteutypa) (Amphisphaeriaceae)
}

\author{
Milan C. Samarakoon ${ }^{1,2,3,4,5}{ }^{-}$, Sajeewa S. N. Maharachchikumbura ${ }^{4} \oplus^{\circ}$, Jian-Kui (Jack) Liu ${ }^{4}$, \\ Kevin D. Hyde ${ }^{3,6}$, Itthayakorn Promputtha ${ }^{1,2, *}$ and Marc Stadler $7, *($ C) \\ 1 Department of Biology, Faculty of Science, Chiang Mai University, Chiang Mai 50200, Thailand; \\ samarakoon_m@cmu.ac.th \\ 2 Research Center in Bioresources for Agriculture, Industry and Medicine, Chiang Mai University, \\ Chiang Mai 50200, Thailand \\ 3 Center of Excellence in Fungal Research, Mae Fah Luang University, Chiang Rai 57100, Thailand; \\ coe-fungal@mfu.ac.th \\ 4 School of Life Science and Technology, University of Electronic Science and Technology of China, \\ Chengdu 611731, China; sajeewa83@yahoo.com (S.S.N.M.); liujiankui@uestc.edu.cn (J.-K.L.) \\ 5 Graduate School, Chiang Mai University, Chiang Mai 50200, Thailand \\ 6 Innovative Institute of Plant Health, Zhongkai University of Agriculture and Engineering, Haizhu District, \\ Guangzhou 510225, China \\ 7 Department of Microbial Drugs, Helmholtz-Zentrum für Infektionsforschung GmbH, Inhoffenstrasse 7, \\ 38124 Braunschweig, Germany \\ * Correspondence: itthayakorn.p@cmu.ac.th (I.P.); marc.stadler@helmholtz-hzi.de (M.S.); \\ Tel.: +66-833-3443-92 (I.P.); +49-531-6181-4240 (M.S.)
}

Received: 24 August 2020; Accepted: 14 September 2020; Published: 17 September 2020

\begin{abstract}
Amphisphaeriaceous taxa (fungi) are saprobes on decaying wood in terrestrial, mangrove, and freshwater habitats. The generic boundaries of the family have traditionally been based on morphology, and the delimitation of genera has always been challenging. Amphisphaeria species have clypeate ascomata and 1-septate ascospores and a coelomycetous asexual morph. Lepteutypa is different from Amphisphaeria in having eutypoid stromata and more than 1-septate ascospores. These main characters have been used for segregation of Lepteutypa from Amphisphaeria for a long time. However, the above characters are overlapping among Amphisphaeria and Lepteutypa species. Therefore, here we synonymized Lepteutypa under Amphisphaeria based on holomorphic morphology and multigene phylogeny. Further, our cluster analysis reveals the relationship between seven morphological traits among Amphisphaeria/Lepteutypa species and suggests those morphologies are not specific to either genus. Three new species (i.e., Amphisphaeria camelliae, A. curvaticonidia, and A. micheliae) are introduced based on morphology and LSU-ITS-RPB2-TUB2 phylogenies. Furthermore, the monotypic genus Trochilispora, which had been accepted in Amphisphaeriaceae, is revisited and synonymized under Hymenopleella and placed in Sporocadaceae.
\end{abstract}

Keywords: 3 new taxa; 6 new combinations; asexual morph; Sporocadaceae; taxonomy

\section{Introduction}

Amphisphaeria, the type genus of Amphisphaeriaceae, was introduced by Cesati and De Notaris [1]. Amphisphaeria has immersed, clypeate, globose, periphysate ostiolate ascomata; visible as raised, blackened, circular dots on the host surface; and several peridial layers with inner hyaline and outer brown cells; filamentous, septate, flexuous paraphyses; 8-spored, cylindrical asci with $\mathrm{J}+$ or $\mathrm{J}-$, discoid, tubular or wedge-shaped apical ring; and 1-septate, ellipsoidal, brown ascospores [1,2]. The coelomycetous asexual morph has solitary or aggregated, globose, dark brown conidiomata with 
a thick-walled peridium, septate, branched, hyaline conidiophores, elongated, conical, thin-walled, septate, hyaline, annellidic conidiogenous cells and hyaline, elongate-fusiform, 1-celled, smooth-walled conidia [3]. Wang et al. [2] revised Amphisphaeria based on herbarium specimens and accepted 12 species. Following consecutive studies, 19 Amphisphaeria species have been accepted [4-9].

Lepteutypa was introduced by Petrak [10] with its type L. fuckelii (三 Massaria fuckelii) which was collected from Germany. Lepteutypa is characterized by scattered, weakly developed eutypoid stroma with a single opening; immersed to semi-immersed, single or clustered perithecia, papillate or short conical ostioles; a cellular peridium; broad, easily broken and numerous paraphyses; 8-spored, cylindrical asci; and oblong, multicellular, pigmented ascospores with thick epispore [10]. Fifteen Lepteutypa species have been published based on above morphology or morpho-phylogenetic studies [9,11-17]. Jaklitsch et al. [16] proposed a neotype for L. fuckelii on Tilia cordata from Belgium, which has aggregated perithecial colonies and 5-septate ascospores. However, in the original generic description, L. fuckelii is characterized by eutypoid stroma as a key character in Lepteutypa [10]. Nevertheless, the aggregated perithecia in the generic description by Petrak [10] were considered to be an eutypoid stroma [16].

Petrak [18] introduced Lepteutypella, which is typified by L. allospora (三 Cladosphaeria allospora). The genus has poorly developed, small, eutypoid, spotty stromata, thin, sub-hyaline, fibrous tissue layer around the ostiole as a distinct clypeus, perithecia with a conical ostiole, broad, simple, very delicate paraphyses (metaphyses), 8-spored, delicate, cylindrical asci and broadly ellipsoidal, multicellular, dark coloured, thick episporous ascospores. However, Lepteutypella has hitherto been regarded as a synonym of Lepteutypa [19].

The presence of multiseptate ascospores in Lepteutypa is a key indicator to differentiate Lepteutypa from Amphisphaeria species. However, some Lepteutypa species, such as L. uniseptate, have 1-septate ascospores, which are morphologically similar to Amphisphaeria, but were phylogenetically related to Lepteutypa in previous studies $[9,16,17]$. Thus, the ascospore septation is not a specific characteristic for the generic delimitation of two genera. The correlations between concepts based on morphology vs. phylogeny of Amphisphaeria and Lepteutypa make taxonomic instability of generic delimitation, which needs further studies.

In this study, we evaluate the morphology and phylogeny of accepted species in Amphisphaeria and Lepteutypa, and synonymize Lepteutypa under Amphisphaeria. Furthermore, as part of our continuous studies on inconspicuous xylariaceous taxa from China and Thailand, we introduce three novel taxa which are associated with senescent plant substrates.

V.P. Abreu, A.W.C. Rosado \& O.L. Pereira introduced Trochilispora in Hyde et al. [20], typified by T. schefflerae from Brazil. The ITS-LSU phylogenies in Hyde et al. [20] showed that T. schefflerae has an affinity to Hymenopleella hippophaeicola. However, Trochilispora was introduced in Amphisphaeriaceae with an uncertainly of the phylogenetic position. Here, we reconstruct the phylogeny including selected taxa and provide evidence for the phylogenetic placement of T. schefflerae.

\section{Materials and Methods}

\subsection{Sample Collection, Isolation and Morphological Studies}

We have been focusing on collecting microfungi from senescent twigs, branches, and culms in both mono- and dicotyledonous plants with emphasis on xylarialean species. Surveys from 2017-2019 investigated several interesting inconspicuous xylariaceous species from northern Thailand [7,21]. In this study, we collected samples from northern Thailand and Sichuan Province, China. Specimens were placed in paper bags and dried at room temperature. External and internal macro-micro structural observations were made as described in Samarakoon et al. [7].

Single spore isolations were carried out as detailed in Chomnunti et al. [22] and germinating spores were transferred aseptically to potato dextrose agar (PDA). The cultures were incubated at 25-30 ${ }^{\circ} \mathrm{C}$ for $4-6$ weeks and colonies observed frequently. The type specimens were deposited in the 
Mae Fah Luang University Herbarium (MFLU), Chiang Rai, Thailand and the Cryptogamic Herbarium, Kunming Institute of Botany, Academia Sinica (HKAS), Kunming, China. Ex-type living cultures were deposited in the Culture Collection at Mae Fah Luang University (MFLUCC) and International Collection of Microorganisms from Plants (ICMP), New Zealand. Facesoffungi and MycoBank numbers are provided as explained in Jayasiri et al. [23] and MycoBank (http://www.MycoBank.org).

\subsection{DNA Extraction, PCR Amplification and Sequencing}

Fresh mycelia were scraped from two-week-old cultures on PDA using sterilized scalpels. Cleaned ascomata were picked up from specimens using sterilized needles. Genomic DNA was extracted using the Ezup DNA Extraction Kit (Sangon Biotech, Shanghai, China) according to the manufacturer's protocol. The internal transcribed spacer (ITS) and partial $28 \mathrm{~S}$ large subunit rDNA (LSU) nuclear ribosomal DNA were amplified using ITS5/ITS4 [24] and LR0R/LR5 [25] primers respectively following $94^{\circ} \mathrm{C} / 30 \mathrm{~s}, 55^{\circ} \mathrm{C} / 50 \mathrm{~s}, 72^{\circ} \mathrm{C} / 60$ s protocol. Partial RNA polymerase II second largest subunit (RPB2) and $\beta$-tubulin (TUB2) were amplified using fRPB2-5f/fRPB2-7cR [26] and T1/T22 [27] primers following $95^{\circ} \mathrm{C} / 45 \mathrm{~s}, 52^{\circ} \mathrm{C} / 50 \mathrm{~s}, 72^{\circ} \mathrm{C} / 60 \mathrm{~s}$ and $95^{\circ} \mathrm{C} / 60 \mathrm{~s}, 54.5^{\circ} \mathrm{C} / 50 \mathrm{~s}, 72^{\circ} \mathrm{C} / 90$ s protocols, respectively. All the PCR protocols were followed by 35 cycles including $94{ }^{\circ} \mathrm{C} / 5 \mathrm{~min}$ initial denaturation and $72{ }^{\circ} \mathrm{C} / 10$ min final extension.

The $25 \mu \mathrm{L}$ total volume of PCR mixture contained $9.5 \mu \mathrm{L}$ of $\mathrm{ddH}_{2} \mathrm{O}, 12.5 \mu \mathrm{L}$ of $2 \mathrm{X}$ PCR Master Mix (TIANGEN Co., China), $1 \mu \mathrm{L}$ of DNA template, and $1 \mu \mathrm{L}$ of forward and reverse primers (10 $\mu \mathrm{M}$ each) in each reaction. PCR amplified products were checked on $1 \%$ agarose electrophoresis gels stained with GoldView I nuclear staining dye $(1 \mu \mathrm{L} / 10 \mathrm{~mL}$ of agarose). Purification and sequencing of PCR products were done by Invitrogen Biotechnology Co. Ltd., Beijing, China. A consensus sequence for each gene region was assembled in SeqMan (DNAStar, Inc., Madison, WI, USA).

\subsection{Phylogenetic Analyses}

Generated ITS, LSU, RPB2, and TUB2 sequences were subjected to BLASTn searches (https://blast. ncbi.nlm.nih.gov) and related sequences were downloaded from GenBank ${ }^{\circledR}$ (Table 1). The individual gene matrix was aligned using MAFFT v7 (https://mafft.cbrc.jp/alignment/server/large.html; [28]) with E-INS-i and L-INS-i Iterative refinement methods, respectively, and improved when necessary in BioEdit v. 7.0 [29]. All absent sequences were coded as missing data and characters were assessed to be unordered and equally weighted.

Evolutionary models were estimated by using MrModeltest 2.2 [30] and model parameters were selected independently for different gene regions under the Akaike information criterion (AIC) implemented in PAUP v. 4.0b10. The GTR+G+I model was the best-fit model for all loci.

Single (LSU, ITS, RPB2, TUB2) and combined (LSU-ITS, LSU-ITS-RPB2-TUB2) matrices were used for phylogenetic analyses in order to compare the topology with previous studies which only used LSU-ITS matrices. Maximum parsimony (MP) analyses were carried out using PAUP v.4.0b 10 [31]. The parameters were set up with tree bisection-reconnection (TBR). Trees were inferred using the heuristic search option with 1000 random sequence additions, with maxtrees set at 1000. Tree length (TL), consistency index $(\mathrm{CI})$, retention index (RI), relative consistency index (RC), and homoplasy index (HI) were calculated for trees generated under different optimality criteria. The Kishino-Hasegawa tests [32] were performed to determine whether trees were significantly different.

Maximum likelihood (ML) analyses were performed at the CIPRES webportal [33] using RAxML-HPC2 on XSEDE (v 8.2.8) with GTR+G+I model and default parameters, and bootstrapping with 1000 replicates [34].

The Bayesian inference (BI) analysis was generated by using Markov Chain Monte Carlo sampling in MrBayes v3.1.2 [35,36] for 3,000,000 generations using four chains with 100 sample frequencies which products 30,000 trees. The first 3000 (10\% from total) trees were the burn-in phase and were discarded. The remaining 27,000 trees were used to calculate the posterior probability (PP). The final alignment and tree were registered in TreeBASE under the submission ID: 26768 (http://www.treebase.org). 
The resulting trees were viewed in FigTree v.1.4.0 [37] and the final layout was done with Adobe Illustrator ${ }^{\circledR}$ CS5 (Adobe Systems, San Jose, CA, USA).

Table 1. List of taxa used in the current phylogenetic study and GenBank acc. nos of DNA sequences. Strains and corresponding sequences that were newly obtained are printed in bold.

\begin{tabular}{|c|c|c|c|c|c|c|}
\hline \multirow{2}{*}{ Species } & \multirow{2}{*}{ Code } & \multicolumn{4}{|c|}{ GenBank Accession Numbers } & \multirow{2}{*}{ References } \\
\hline & & LSU & ITS & RPB2 & TUB2 & \\
\hline $\begin{array}{l}\text { Achaetomium } \\
\text { macrosporum }\end{array}$ & CBS 532.94 & KX976699 & KX976574 & KX976797 & KX976915 & [38] \\
\hline $\begin{array}{c}\text { Amphisphaeria } \\
\text { acericola }\end{array}$ & MFLU 16-2479 & MK640424 & MK640423 & - & - & {$[8]$} \\
\hline $\begin{array}{c}\text { Amphisphaeria } \\
\text { acericola }\end{array}$ & MFLUCC 14-0842* & MF614131 & MF614128 & - & - & [8] \\
\hline $\begin{array}{c}\text { Amphisphaeria } \\
\text { camelliae }\end{array}$ & HKAS $107021 *$,a & MT756615 & MT756621 & MT789850 & MT774368 & This study \\
\hline $\begin{array}{c}\text { Amphisphaeria } \\
\text { camelliae }\end{array}$ & MFLUCC 20-0122 b & MT756616 & MT756622 & MT789851 & MT774369 & This study \\
\hline $\begin{array}{l}\text { Amphisphaeria } \\
\text { curvaticonidia }\end{array}$ & HKAS $102288^{a}$ & MT756618 & MT756624 & MT789853 & - & This study \\
\hline $\begin{array}{l}\text { Amphisphaeria } \\
\text { curvaticonidia }\end{array}$ & MFLUCC 18-0620 *,b & MT756617 & MT756623 & MT789852 & - & This study \\
\hline $\begin{array}{l}\text { Amphisphaeria } \\
\text { flava }\end{array}$ & MFLUCC 18-0361 * & MH971234 & MH971224 & - & MK033638 & [7] \\
\hline $\begin{array}{l}\text { Amphisphaeria } \\
\text { fuckelii }\end{array}$ & WU 33555 & KT949903 & КT949903 & - & - & [16] \\
\hline $\begin{array}{l}\text { Amphisphaeria } \\
\text { fuckelii }\end{array}$ & CBS 140409 * & KT949902 & KT949902 & MH554918 & MH554677 & {$[16,39]$} \\
\hline $\begin{array}{c}\text { Amphisphaeria } \\
\text { mangrovei }\end{array}$ & NFCCI-4247* & MG844275 & MG844283 & - & - & [6] \\
\hline $\begin{array}{l}\text { Amphisphaeria } \\
\text { micheliae }\end{array}$ & HKAS 107012 *,a & MT756619 & MT756625 & MT789854 & MT774370 & This study \\
\hline $\begin{array}{l}\text { Amphisphaeria } \\
\text { micheliae }\end{array}$ & MFLUCC $20-0121^{b}$ & MT756620 & MT756626 & MT789855 & MT774371 & This study \\
\hline $\begin{array}{c}\text { Amphisphaeria } \\
\text { neoaquatica }\end{array}$ & MFLUCC 14-0045 * & MK835805 & MK828607 & - & - & [17] \\
\hline $\begin{array}{c}\text { Amphisphaeria } \\
\text { qujingensis }\end{array}$ & KUMCC 19-0186 & MN707567 & MN707568 & - & - & [9] \\
\hline $\begin{array}{l}\text { Amphisphaeria } \\
\text { qujingensis }\end{array}$ & KUMCC 19-0187* & MN556316 & MN477033 & - & - & [9] \\
\hline $\begin{array}{l}\text { Amphisphaeria } \\
\text { sambuci }\end{array}$ & CBS $131707^{*}$ & KT949904 & KT949904 & MH554911 & MH704632 & {$[16,39]$} \\
\hline $\begin{array}{c}\text { Amphisphaeria } \\
\text { sambuci }\end{array}$ & WU 33557 & KT949905 & КT949905 & - & - & [16] \\
\hline $\begin{array}{c}\text { Amphisphaeria } \\
\text { sambuci }\end{array}$ & WU 33558 & KT949906 & KT949906 & - & - & [16] \\
\hline $\begin{array}{c}\text { Amphisphaeria } \\
\text { sorbi }\end{array}$ & MFLUCC 13-0721* & KP744475 & KR092797 & - & - & [5] \\
\hline $\begin{array}{c}\text { Amphisphaeria } \\
\text { thailandica }\end{array}$ & MFLU 18-0794 * & MH971235 & MH971225 & MK033640 & MK033639 & [7] \\
\hline $\begin{array}{c}\text { Amphisphaeria } \\
\text { umbrina }\end{array}$ & AFTOL-ID 1229 & FJ176863 & FJ176809 & - & - & [40] \\
\hline $\begin{array}{c}\text { Amphisphaeria } \\
\text { uniseptata }\end{array}$ & CBS $114967 *$ & MH554197 & - & MH554878 & MH554638 & [39] \\
\hline $\begin{array}{c}\text { Amphisphaeria } \\
\text { yunnanensis }\end{array}$ & KUMCC 19-0188* & MN556306 & MN477177 & - & - & [9] \\
\hline $\begin{array}{l}\text { Amphisphaeria } \\
\text { yunnanensis }\end{array}$ & KUMCC 19-0189 & MN550992 & MN550997 & - & - & [9] \\
\hline $\begin{array}{l}\text { Anungitea } \\
\text { eucalyptorum }\end{array}$ & CBS 137967 & KJ869176 & KJ869118 & - & - & [41] \\
\hline
\end{tabular}


Table 1. Cont.

\begin{tabular}{|c|c|c|c|c|c|c|}
\hline \multirow{2}{*}{ Species } & \multirow{2}{*}{ Code } & \multicolumn{4}{|c|}{ GenBank Accession Numbers } & \multirow{2}{*}{ References } \\
\hline & & LSU & ITS & RPB2 & TUB2 & \\
\hline $\begin{array}{l}\text { Anungitea } \\
\text { grevilleae }\end{array}$ & CBS 141282 & KX228304 & KX228252 & - & - & [42] \\
\hline $\begin{array}{l}\text { Bagadiella } \\
\text { lunata }\end{array}$ & CBS $124762 *$ & GQ303300 & GQ303269 & - & - & [43] \\
\hline Bartalinia pini & CBS $143891 *$ & MH554330 & MH554125 & MH555033 & MH554797 & [39] \\
\hline $\begin{array}{l}\text { Bartalinia } \\
\text { pondoensis }\end{array}$ & CBS 125525 * & MH875078 & MH863602 & MH554904 & MH554663 & {$[39,40]$} \\
\hline $\begin{array}{c}\text { Beltrania } \\
\text { pseudorhombica }\end{array}$ & CBS 138003 * & KJ869215 & KJ869158 & MH555032 & - & {$[39,41]$} \\
\hline $\begin{array}{l}\text { Beltrania } \\
\text { rhombica }\end{array}$ & CBS 123.58 & MH869260 & MH857718 & MH554899 & MH704631 & {$[39,44]$} \\
\hline $\begin{array}{l}\text { Beltraniella } \\
\text { endiandrae }\end{array}$ & CBS 137976 * & KJ869185 & KJ869128 & - & - & [41] \\
\hline $\begin{array}{c}\text { Beltraniopsis } \\
\text { neolitseae }\end{array}$ & CBS 137974 * & KJ869183 & KJ869126 & - & - & [41] \\
\hline $\begin{array}{c}\text { Castanediella } \\
\text { acaciae }\end{array}$ & CBS $139896^{*}$ & KR476763 & KR476728 & - & - & {$[45]$} \\
\hline $\begin{array}{c}\text { Castanediella } \\
\text { brevis }\end{array}$ & KUMCC 18-0132 * & MH806358 & MH806361 & - & - & [46] \\
\hline $\begin{array}{c}\text { Castanediella } \\
\text { eucalypti }\end{array}$ & CBS $139897 *$ & KR476758 & KR476723 & - & - & [45] \\
\hline $\begin{array}{l}\text { Castanediella } \\
\text { eucalypticola }\end{array}$ & CBS 141317 * & KX228317 & KX228266 & - & KX228382 & [42] \\
\hline $\begin{array}{l}\text { Chaetomium } \\
\text { elatum }\end{array}$ & CBS 374.66 & MH870466 & KC109758 & KF001820 & КC109776 & {$[38,44]$} \\
\hline $\begin{array}{l}\text { Clypeophysalospora } \\
\text { latitans }\end{array}$ & CBS 141463 * & KX820261 & KX820250 & - & - & [47] \\
\hline $\begin{array}{l}\text { Cylindrium } \\
\text { corymbiae }\end{array}$ & CBS 146087 * & MT223887 & MT223792 & MT223679 & MT223732 & [48] \\
\hline $\begin{array}{l}\text { Cylindrium } \\
\text { grande }\end{array}$ & СРС 35403 * & MK876425 & MK876384 & MK876481 & MK876502 & [49] \\
\hline $\begin{array}{l}\text { Heterotruncatella } \\
\text { acacigena }\end{array}$ & CBS 143880 * & MH554295 & MH554084 & MH554996 & MH554756 & [39] \\
\hline $\begin{array}{l}\text { Heterotruncatella } \\
\text { vinaceobubalina }\end{array}$ & CBS 143897 & MH554341 & MH554139 & MH555045 & MH554812 & [39] \\
\hline $\begin{array}{l}\text { Hymenopleella } \\
\text { hippophaeicola }\end{array}$ & CBS 140410 * & KT949901 & KT949901 & MH554919 & MH554678 & {$[16,39]$} \\
\hline $\begin{array}{c}\text { Hymenopleella } \\
\text { polyseptata }\end{array}$ & CBS 143887 * & MH554321 & MH554116 & MH555024 & MH554789 & [39] \\
\hline $\begin{array}{l}\text { Hymenopleella } \\
\text { schefflerae }\end{array}$ & COAD $2371 *$ & MH084761 & MH128360 & - & MH231215 & [20] \\
\hline $\begin{array}{l}\text { Hymenopleella } \\
\text { austroafricana }\end{array}$ & CBS $143886^{*}$ & MH554320 & MH554115 & MH555023 & MH554788 & [39] \\
\hline $\begin{array}{l}\text { Neophysalospora } \\
\text { eucalypti }\end{array}$ & CBS 138864 * & KР004490 & KP004462 & - & - & {$[50]$} \\
\hline $\begin{array}{l}\text { Phlogicylindrium } \\
\text { uniforme }\end{array}$ & CBS 131312 * & JQ044445 & JQ044426 & MH554910 & MH704634 & {$[39,51]$} \\
\hline $\begin{array}{l}\text { Phlogicylindrium } \\
\text { eucalyptorum }\end{array}$ & CBS 111680 & KF251707 & KF251204 & KF252209 & KF252698 & [52] \\
\hline $\begin{array}{c}\text { Plectosphaera } \\
\text { eucalypti }\end{array}$ & CBS $120063 *$ & DQ923538 & DQ923538 & - & - & [53] \\
\hline $\begin{array}{l}\text { Robillarda } \\
\text { roystoneae }\end{array}$ & CBS 115445 * & MH874545 & KR873254 & MH554880 & KR873317 & {$[39,44,54]$} \\
\hline
\end{tabular}


Table 1. Cont.

\begin{tabular}{|c|c|c|c|c|c|c|}
\hline \multirow{2}{*}{ Species } & \multirow{2}{*}{ Code } & \multicolumn{4}{|c|}{ GenBank Accession Numbers } & \multirow{2}{*}{ References } \\
\hline & & LSU & ITS & RPB2 & TUB2 & \\
\hline $\begin{array}{c}\text { Seimatosporium } \\
\text { rosae }\end{array}$ & MFLUCC 14-0621 * & MH823070 & LT853105 & LT853153 & LT853253 & {$[3,55]$} \\
\hline $\begin{array}{l}\text { Seiridium } \\
\text { marginatum }\end{array}$ & CBS $140403 *$ & MH878679 & KT949914 & LT853149 & LT853249 & {$[16,44,55]$} \\
\hline $\begin{array}{l}\text { Sordaria } \\
\text { fimicola }\end{array}$ & CBS 723.96 & MH874231 & - & DQ368647 & - & {$[44,56]$} \\
\hline
\end{tabular}

Types and authentic strains are indicated with $\left(^{*}\right)$. Codes with ${ }^{\mathrm{a}}$ and ${ }^{\mathrm{b}}$ are denoted holotypes and ex-type cultures, respectively. Missing sequences are indicated by (-). Newly generated sequences are in bold. Abbreviations: AFTOL-ID-Assembling the Fungal Tree of Life; CBS-Centraalbureau voor Schimmelcultures, Utrecht, The Netherlands; COAD—Culture Collection of the Universidade Federal de Viçosa, Brazil; CPC—Culture collection of Pedro Crous, housed at CBS; HKAS-The Herbarium of Cryptogams Kunming Institute of Botany Academia Sinica, Kunming, China; KUMCC-Kunming Institute of Botany Culture Collection, Kunming, China; MFLU—Mae Fah Luang University Herbarium, Chiang Rai, Thailand; MFLUCC—Mae Fah Luang University Culture Collection, Chiang Rai, Thailand; NFCCI-National Fungal Culture Collection of India, Agharkar Research Institute, India. WU-Herbarium of the Institute of Botany, University of Vienna, Austria.

\subsection{Cluster Analysis}

A cluster analysis was performed to assess morphological similarities of Amphisphaeria and Lepteutypa taxa. The presence of poorly- (0) or well- (1) developed clypeus; solitary (0) or solitary/aggregated (0.5) or aggregated (1) nature of ascomata; $1 / w$ ratio of asci $\leq 15(0)$ or $>15$ (1); J- (0) or J+ (1) apical ring; $1 / \mathrm{w}$ ratio of ascospores $\leq 2.8(0)$ or $>2.8$ (1); one septaum (0) or more than one septum (1) in ascospores; and the absence (0) or presence (1) of a mucilaginous sheath around ascospores of Amphisphaeria and Lepteutypa species were used for the analysis.

The analysis was conducted using Python 3.8 coupled with SciPy 1.5.1 package. We obtained a dendrogram using the unweighted pair group method with arithmetic mean (UPGMA) algorithm and also obtained the Average distance measure. The dendrogram of obtained results was plotted using Matplotlib 3.3.0 package. The heatmap was obtained in a similar way. Plotting was performed by using Seaborn 0.10.1 (https://docs.scipy.org).

\section{Results}

\subsection{Topology of Phylogenetic Analyses}

The LSU-ITS alignment comprised 1374 characters (LSU 1-786, ITS 787-1374) while the LSU-ITS-RPB2-TUB2 combined alignment comprised 2515 characters (LSU 1-786, ITS 787-1377, RPB2 1378-2212, TUB2 2213-2515) including 56 strains.

We follow LSU-ITS-RPB2-TUB2 to show the relationship among related taxa here (Figure 1). The best scoring RAxML tree with a final likelihood value of-1224.694904 is presented. The matrix had 1227 distinct alignment patterns, with $28.04 \%$ of undetermined characters or gaps. Estimated base frequencies were as follows; $\mathrm{A}=0.247366, \mathrm{C}=0.234669, \mathrm{G}=0.265996, \mathrm{~T}=0.251970$; substitution rates $\mathrm{AC}=1.117478, \mathrm{AG}=3.507552, \mathrm{AT}=1.477282, \mathrm{CG}=1.121674, \mathrm{CT}=6.681156, \mathrm{GT}=1.000000$; gamma distribution shape parameter $\alpha=0.485915$. The ML, MP, and BY phylogenetic trees resulting from analyses of the alignment of LSU-ITS were different among taxa within the Amphisphaeriaceae (Figure S1). ML and BY results using LSU-ITS-RPB2-TUB2 combined matrix were similar in topologies, and Amphisphaeriaceae was comprised of two well-supported clades containing Amphisphaeria species (clade $\mathrm{Y}$ ) and species that had previously been classified under the genus Lepteutypa (clade X). Amphisphaeria curvaticonidia (HKAS 102288, MFLUCC 18-0620) formed a basal lineage to all the other amphisphaeriaceous taxa in only MP analysis by using the LSU-ITS-RPB2-TUB2 combined matrix. 


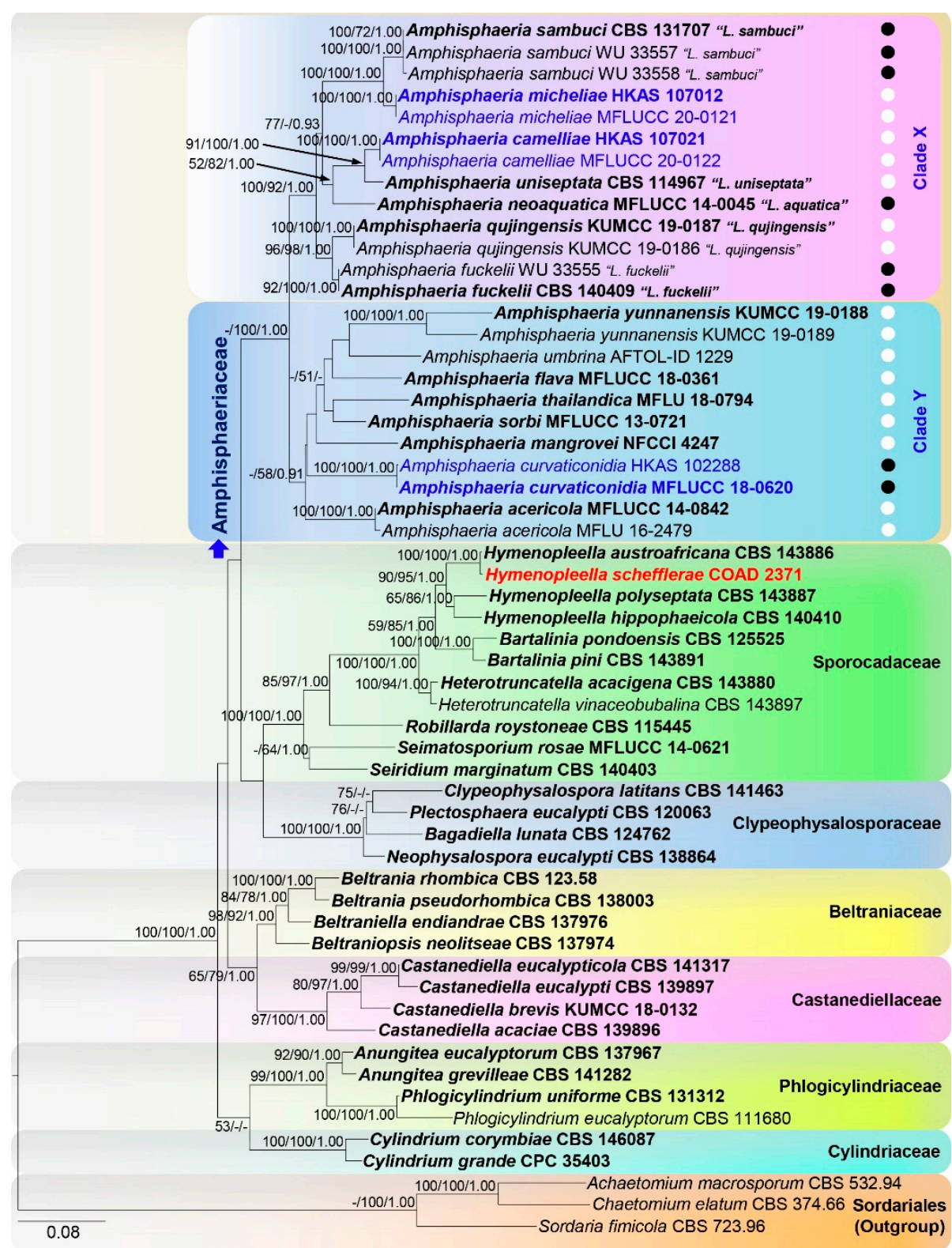

Figure 1. ML tree revealed by RAxML from an analysis of the LSU-ITS-RPB2-TUB2 matrix of the Amphisphaeriaceae and selected families of Amphisphaeriales. Bootstrap supports $(\geq 50 \%)$ of MP and ML and the posterior probability values $(\geq 0.9)$ of $\mathrm{BI}$ analyses are indicated above or below the respective branches. Newly generated sequences are in blue and type strains are in bold. The tree is rooted to Achaetomium macrosporum, Chaetomium elatum, and Sordaria fimicola (Sordariales). The scale bar represents the expected number of nucleotide substitutions per site. Ascospore septation among taxa are shown in white (one septum) and black (more than one septum) circles. Taxon in red denotes topological conflict with previous phylogenies. Previous taxa are in "•".

The maximum parsimony dataset consisted of 2515 characters, of which 1430 were constant, 881 parsimony-informative (35.03\%), and 204 parsimony-uninformative. The parsimony analysis of the data matrix resulted in 1000 equally most parsimonious trees with a length of 3898 steps $(C I=0.445$, $\mathrm{RI}=0.671, \mathrm{RC}=0.299, \mathrm{HI}=0.555$ ) in the first tree.

Amphisphaeria curvaticonidia (HKAS 102288, MFLUCC 18-0620; 100\%/100\%/1.00 PP) formed a clade with poor statistical support. Amphisphaeria camelliae (HKAS 107021, MFLUCC 20-0122; 100\%/100\%/1.00 PP) is sister to "Lepteutypa uniseptata" CBS 114967 (91\%/100\%/1.00 PP). Amphisphaeria 
micheliae (HKAS 107012, MFLUCC 20-0121; 100\%/100\%/1.00 PP) formed a clade sister to "L. sambuci" (CBS 131707, WU 33557 and WU 33558) with strong statistical support (100\%/100\%/1.00 PP). The strain "Trochilispora schefflerae" (COAD 2371) clustered with Hymenopleella austroafricana (CBS 143886) with high statistical support (100\%/100\%/1.00 PP) in Sporocadaceae.

The ITS sequence of "Lepteutypa uniseptata"; CBS 114967 (MH553979) is dubious because it appeared highly similar to Robillarda species in a BLASTn search and clustered in Sporocadaceae in our ITS-based phylogenies, which is why it has been excluded from our final analyses.

\subsection{Cluster Analysis}

The cluster analysis was comprised of 37 species with seven characters (Figure 2). There are three clusters (A, B and C). The type of species of Amphisphaeria; A. umbrina and the type of "Lepteutypa"; "L. fuckelii" cluster with clusters B and C, respectively. Species in cluster A shared asci $1 / \mathrm{w}$ greater than 15. Clusters B and C were mainly distinguished by having 1-septate (B) and multiseptate (C) ascospores. All other characteristics were distributed among the species without a unique characteristic for each genus.

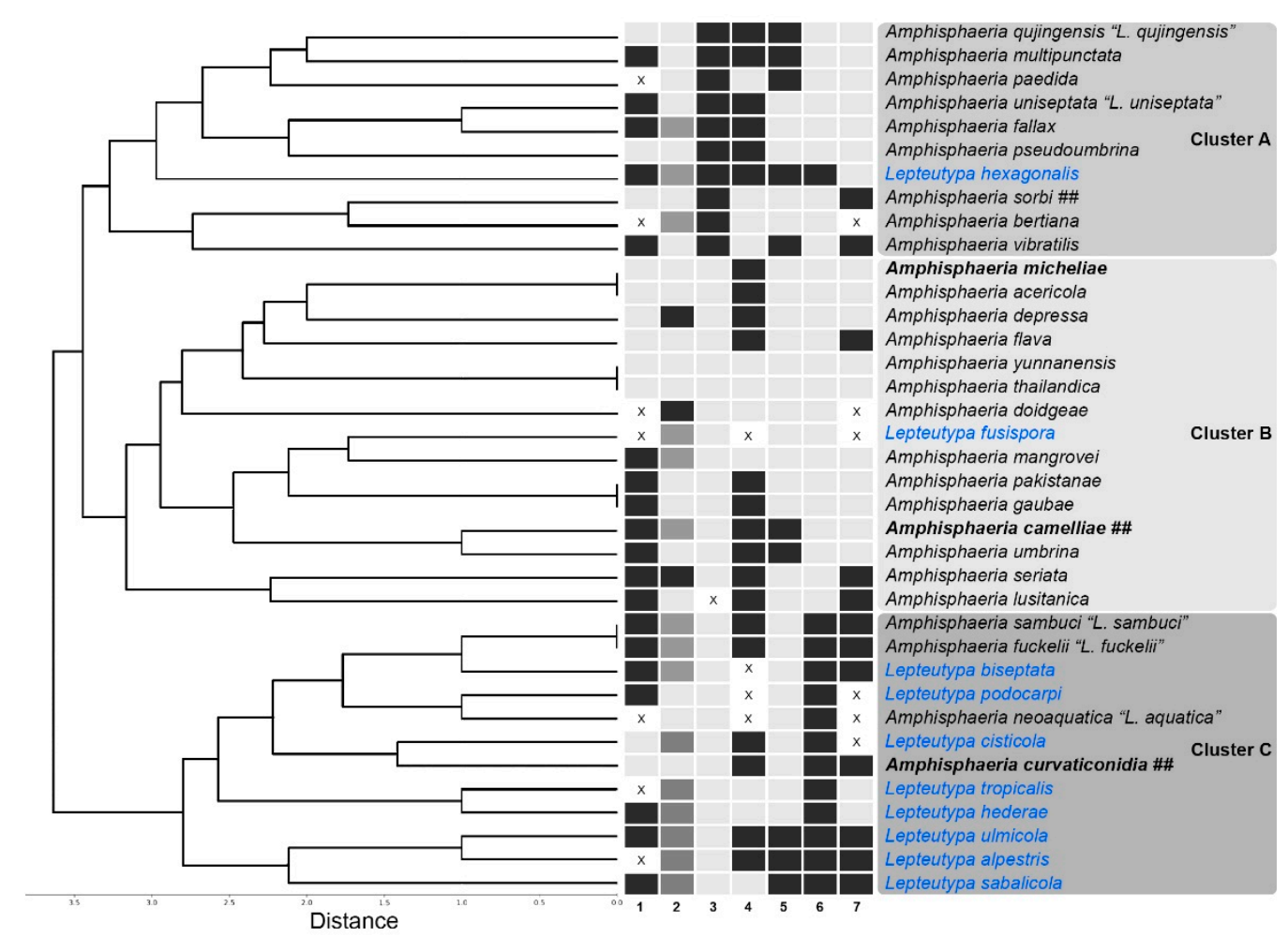

Figure 2. Cluster analysis dendrogram showing similarity among Amphisphaeria and Lepteutypa species (linkage algorithm paired group UPGMA; Average Distance measure). Characteristics: (1) nature of the clypeus; (2) nature of the ascomata; (3) 1/w ratio of asci; (4) apical ring; (5) 1/w ratio of ascospores; (6) ascospore septation; and (7) mucilaginous sheath around ascospores. " $X$ " denotes missing data. Newly introduced species are in bold. Taxa which needed to be revised are in blue. Holomorphic taxa are denoted as "\#\#".

\subsection{Taxonomy}

\subsubsection{Amphisphaeria}

Amphisphaeria Ces. \& De Not., Comm. Soc. crittog. Ital. 1(fasc. 4): 223 (1863), emend.

MycoBank: MB173; Facesoffungi number: FoF02099

= Poikiloderma Füisting, Bot. Ztg. 26: 369 (1868) 
$=$ Massariopsis Niessl, Verh. nat. Ver. Brünn 14: 199 (1876)

= Phorcys Niessl, Verh. nat. Ver. Brünn 14: 200 (1876)

= Conisphaeria Cooke, Grevillea 7(no. 43): 86 (1879)

$=$ Massariella Speg., Anal. Soc. cient. argent. 9(4): in tabula [facing p. 192) (1880)

= Lepteutypa Petr., Annls mycol. 21(3/4): 276 (1923)

$=$ Rhynchostomopsis Petr. \& Syd., Annls mycol. 21(5/6): 377 (1923)

= Lepteutypella Petr., Annls mycol. 23(1/2): 98 (1925)

= Macrothelia M. Choisy, Bull. mens. Soc. linn. Soc. Bot. Lyon 18: 107 (1949)

Saprobic on woody branches, twigs and culms in terrestrial, freshwater, and mangrove habitats. Sexual morph: appearing as slightly raised, black dots on host surface, often surrounded by a dark or light-coloured, halo-like area. Pseudostromata, when present, are made up of host cells and brown to black fungal hyphae. The Clypeus is often poorly developed. Ascomata: perithecial, scattered, solitary or clustered, immersed, erumpent or rarely superficial, globose, subglobose or ellipsoidal, coriaceous, dark brown, papillate ostiole. Papilla: narrow, conical, periphysate, often umbilicate. Periphyses: hyaline, filamentous. Peridium: two-layered, with an outer layer comprising dark brown cells arranged in a textura angularis and inner layer comprising thin-walled, hyaline cells. Hamathecium: comprising numerous, filamentous, septate, slightly tapering paraphyses. Asci: 8-spored, unitunicate, cylindrical, indistinctly pedicellate, apex rounded, with $\mathrm{J}+$ or J- apical ring. Ascospores: uniseriate to overlapping uniseriate, light brown to dark brown, ellipsoid to fusiform, rarely curved, 1-3-septate, not or slightly constricted at the septum, rarely 2-4(6)-distoseptate, smooth-walled, some guttulate, with or without a mucilaginous sheath. Asexual morph: Coelomycetous. Conidiomata: solitary or aggregated, globose to sub-globose, dark brown. Peridium: comprised of thick-walled, septate, brown mycelium. Conidiophores: septate, branched, thick-walled, hyaline to light brown. Conidiogenous cells: elongated, thin-walled, septate, hyaline, annellidic. Conidia: hyaline, elongate-fusiform, 1-celled with or without appendage derived from the middle of the conidia, smooth-walled.

Type species: Amphisphaeria umbrina (Fr.) De Not., Sfer. Ital.: 69 (1863)

MycoBank: MB222981; Facesoffungi number: FoF08735

三Sphaeria umbrina Fr., Syst. mycol. (Lundae) 2(2): 461 (1823) nom. sanct.

= Sphaeria mammillaris Schumach., Enum. pl. (Kjbenhavn) 2: 157 (1803)

= Sphaeropsis conica Lév., in Demidov, Voyage dans la Russie Meridionale et la Crimeé, par la Hongrie, la Valachie et la Moldavie 2: 112 (1842)

= Diplodia conica (Lév.) Lév., Annls Sci. Nat., Bot., sér. 3 9: 258 (1848)

= Amphisphaeria conica (Lév.) Ces. \& De Not., Comm. Soc. crittog. Ital. 1(fasc. 4): 224 (1863)

= Hypocrea gelatinosa var. umbrina (Fr.) Sacc., Syll. fung. (Abellini) 2: 524 (1883)

= Kirschsteiniella conica (Lév.) Petr., Sydowia 7(1-4): 57 (1953)

Typus: Italy, Flaventino, on trunk of Ulmus sp. (Ulmaceae), Nov. 1860, L. Caldesi, Rabenhorst Fungi Europaei 327 (RO, epitype).

Notes: Fries [57] described Sphaeria umbrina on the wood of Alnus (Betulaceae) from Sweden. Cesati and de Notaris [1] introduced Amphisphaeria without a type species. Petrak [10] revisited the morphology of the Amphisphaeria umbrina on the bark of Ulmus (Ulmaceae) from Italy and proposed it as the type of species of Amphisphaeria. Consecutive studies from Clements and Shear [58], Müller and Arx [59], and Korf [60] accepted A. umbrina as the type species of Amphisphaeria represented by Sphaeria umbrina. Hyde et al. [61] re-examined a specimen of S. umbrina from the collection of Cesati and de Notaris [1], also which was used by Petrak [10] for description. The specimen was proposed as the epitype for A. umbrina. Hyde et al. [61] provided another A. umbrina specimen from Austria on Quercus petraea (Fagaceae) (AFTOL-ID 1229; CBS 172.96). Amphisphaeria umbrina is distributed in temperate habitats on Quercus (Fagaceae), Salix (Salicaceae), Tilia (Malvaceae) and Ulmus (Ulmaceae) [61]. In addition, Amphisphaeria has been described from Alnus (Betulaceae), Fraxinus (Oleaceae), Quercus (Fagaceae), Salix (Salicaceae) and Ulmus (Ulmaceae) [62]. 
Petrak [10] introduced Lepteutypa to accommodate species with eutypoid stroma and multicellular ascospores different from Amphisphaeria. Lepteutypa species do not possess eutypoid stroma in their morphological descriptions, figures, and illustrations except aggregated ascomata. Jaklitsch et al. [16] proposed a neotype for Lepteutypa fuckelii, the type species of the genus, which has scattered or aggregated ascomata on the host but not eutypoid stroma. Jaklitsch et al. [16] further noted that Petrak [10] interpreted those aggregated perithecial colonies as eutypoid stromata. Among previously known Lepteutypa species, L. alpestris, L. cisticola, L. fusispora, L. hederae and L. tropicalis also possess aggregated perithecia, while L. hexagonalis possesses two perithecia under a single clypeus rarely. The aggregated ascomata also can be observed in A. bertiana and A. seriata.

Amphisphaeria and Lepteutypa were previously separated based on stromatic nature and ascospore septation. However, with the introduction of Amphisphaeria camelliae and A. micheliae, which are typical of Amphisphaeria and not "Lepteutypa" where they cluster, we conclude the Amphisphaeria and "Lepteutypa" are congeneric. There is no distinct characteristic used to separate Amphisphaeria (clade Y) and "Lepteutypa" (clade X) clusters in Figure 1. Both clusters have 2-celled and multicelled ascospores. No single characteristic exists in one clade. The predicament here is whether to follow the molecular data, which indicates there are two distinct genera (Amphisphaeria and Lepteutypa) or the morphological data which indicates the group is one genus (Amphisphaeria). We adopt a single genus, Amphisphaeria, due to the morphological similarity. However, further studies with fresh collections may resolve the taxonomic relationships in Amphisphaeriaceae and sexual asexual connections.

The coelomycetous asexual morph of Amphisphaeria sorbi is the only asexual record in Amphisphaeriaceae. Several morphological records of pestaloid-like asexual morphs for "Lepteutypa" have been suggested, but not confirmed [63]. In our study, we obtained two asexual morphs which are not pestaloid-like, but similar to the coelomycetous asexual morph of $A$ sorbi. Since there is lack of sequence data for most of the "Lepteutypa" species, here we provided five taxonomic combinations of "Lepteutypa" species which have molecular data. However, the remaining "Lepteutypa" species are treated as ambiguous taxa and need to be revisited with molecular and morphology data in further studies.

\subsubsection{Additional Accepted Species in Amphisphaeria}

Amphisphaeria acericola Senan., Camporesi \& K.D. Hyde, Phytotaxa 403(4): 285-292 (2019) MycoBank: MB553774; Facesoffungi number: FoF03594

Typus: Italy, Province of Forlì-Cesena, Galeata, Strada San Zeno, on a branch of Acer campestre (Sapindaceae), 26 Mar 2014, E. Camporesi, IT 1779 (MFLU 16-2479, holotype); ex-type living culture MFLUCC 14-0842.

Notes: Amphisphaeria acericola is similar to A. pseudoumbrina in having immersed, oblate ascomata, $\mathrm{J}+$, a discoid apical ring, cylindrical asci with rugose-walled, brown, uniseptate ascospores, but different in having non-clypeate ascomata, peridium with textura angularis cells, and aseptate, cellular paraphyses. The LSU-ITS phylogeny of A. acericola forms a basal clade distinct from other Amphisphaeria species.

Amphisphaeria bertiana Fairm., Proc. Rochester Acad. Sci. 4: 217 (1906)

MycoBank: MB190709; Facesoffungi number: FoF08738

Typus: USA, New York, Lyndonville, in cavities at the end of a rotting log, Oct. 1905, Fairman (CUP, holotype).

Notes: Wang et al. [2] re-examined the holotype. Amphisphaeria bertiana has erumpent or superficial ascomata on a subiculum and $\mathrm{J}-$ apical ring.

Amphisphaeria camelliae Samarak., Jian K. Liu \& K.D. Hyde, sp. nov. Figures 3 and 4 

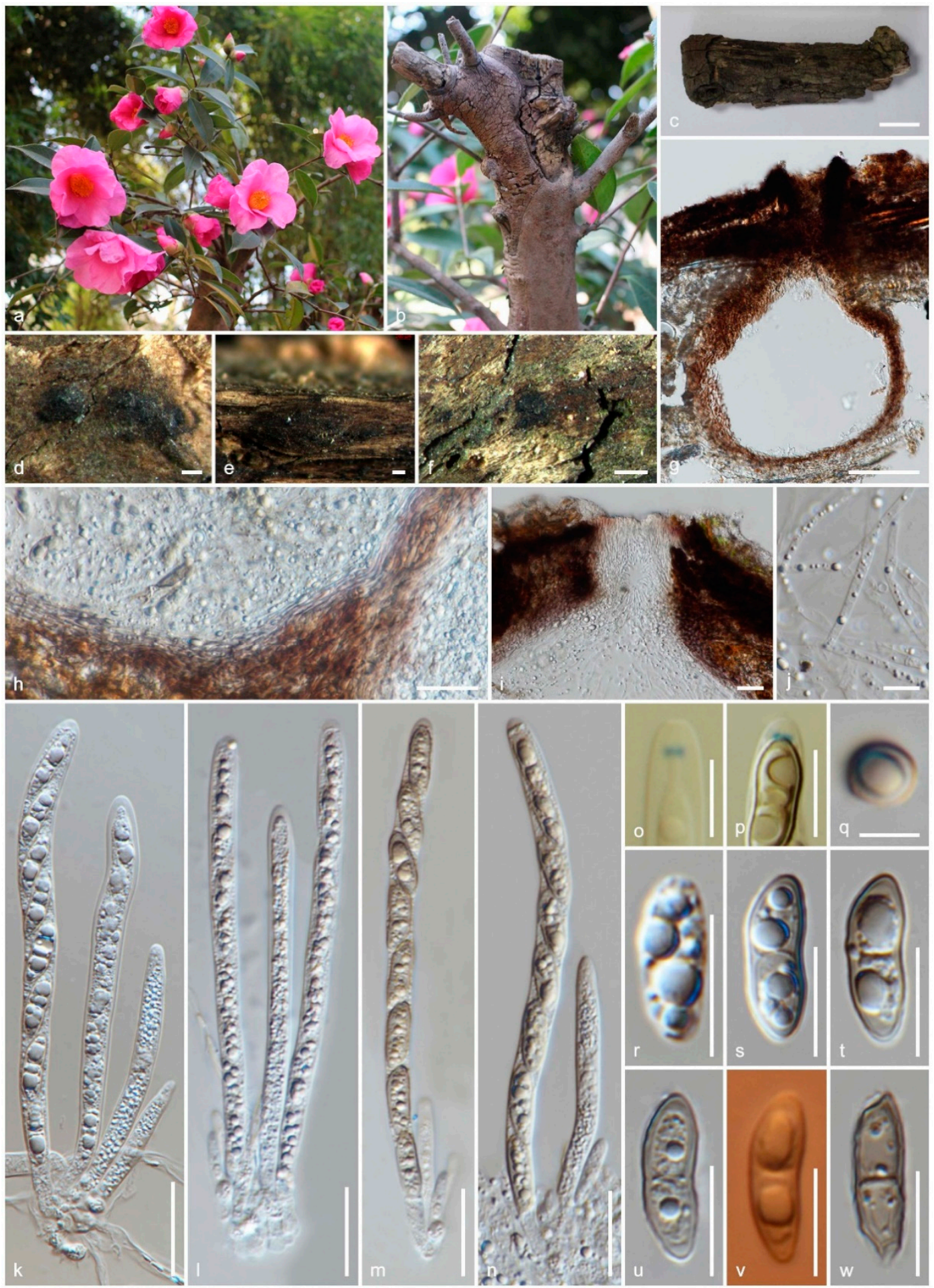

Figure 3. The sexual morph of Amphisphaeria camelliae (HKAS 107021, holotype). (a,b) Host Camellia japonica; (c) substrate; (d-f) ascomata on the substrate; (g) vertical section of ascoma; (h) peridium; (i) ostiole; (j) paraphyses; (k-n) asci; (o,p) apical ring bluing in Melzer's reagent; (q) ascospore top view; $(\mathbf{r}-\mathbf{w})$ ascospores (v in Congo Red). Scale bars are set at (c) $1 \mathrm{~cm} ;(\mathbf{f}) 500 \mu \mathrm{m} ;(\mathbf{d}, \mathbf{e}) 200 \mu \mathrm{m} ;(\mathbf{g}) 100 \mu \mathrm{m}$; $(\mathbf{h}, \mathbf{i}, \mathbf{k}-\mathbf{n}) 20 \mu \mathrm{m} ;(\mathbf{o}, \mathbf{p}, \mathbf{r}-\mathbf{w}) 10 \mu \mathrm{m} ;(\mathbf{q}) 5 \mu \mathrm{m}$. 


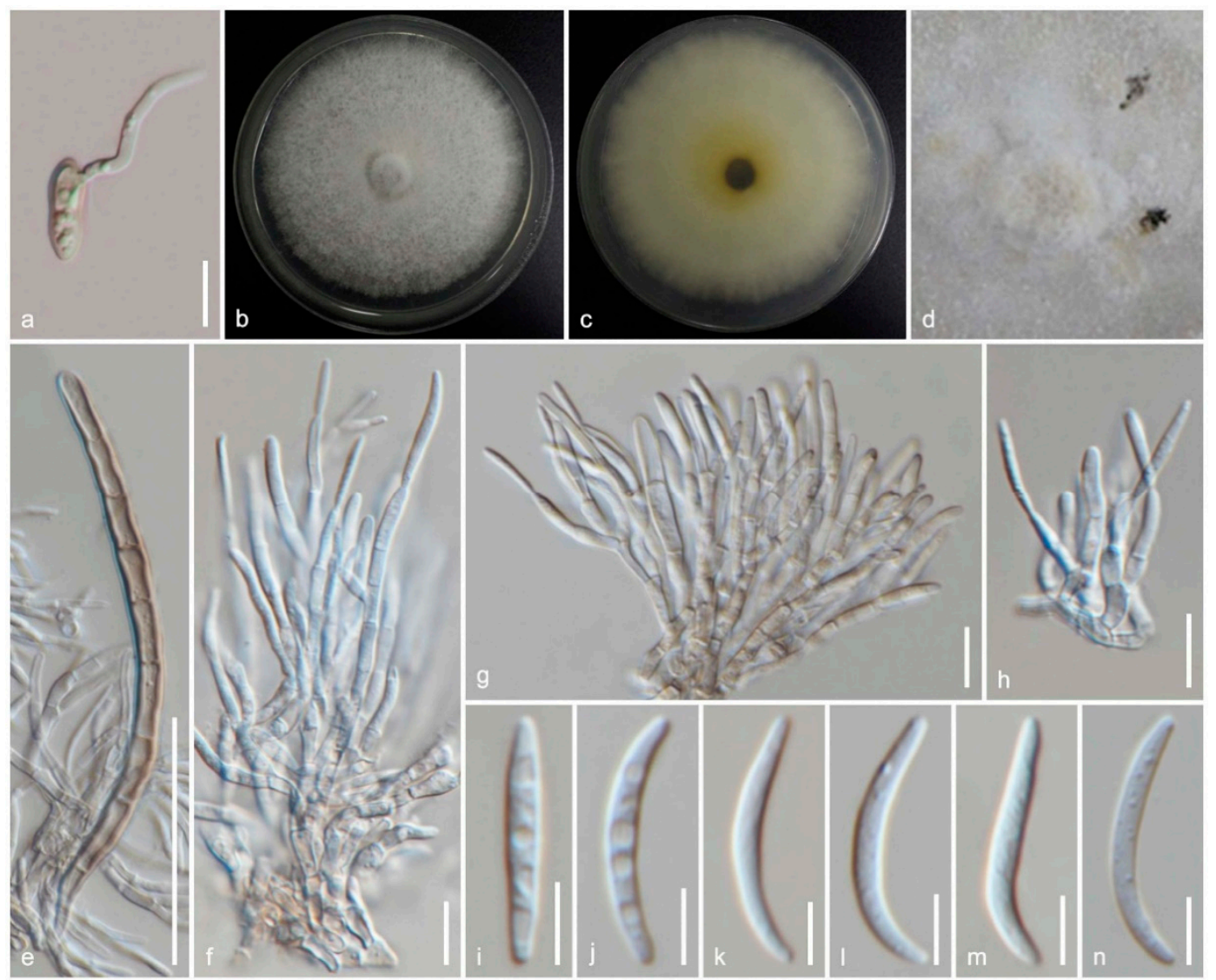

Figure 4. The asexual morph of Amphisphaeria camelliae (MFLUCC 20-0122, ex-type living culture). (a) Germinating ascospore; (b) upper view, (c) reverse view of the 2 weeks old colony on PDA; (d) conidiomata in the culture; (e) setae; $(\mathbf{f}-\mathbf{h})$ conidiophores, conidiogenous cells and conidiogenesis; (i-n) conidia. Scale bars are set at (e) $50 \mu \mathrm{m} ;(\mathbf{a}, \mathbf{f}-\mathbf{h}) 10 \mu \mathrm{m} ;(\mathbf{i}-\mathbf{n}) 5 \mu \mathrm{m}$.

MycoBank: MB836110; Facesoffungi number: FoF08740

Etymology: The specific epithet reflects the host genus Camellia.

Holotype: HKAS 107021

Saprobic on the dead wood of Camellia japonica (Theaceae). Sexual morph: Ascomata: 300-480 $\mu \mathrm{m}$ high $\times 160-310 \mu \mathrm{m}$ diameter $(\mathrm{M}=410 \times 260 \mu \mathrm{m}, n=5)$, immersed, visible as black spots covered with pale brown and blackish area, solitary or aggregated, scattered, globose to subglobose, papillate ostiole 80-150 $\mu \mathrm{m}$ high $\times 50-85 \mu \mathrm{m}$ diameter $(\mathrm{M}=110 \times 60 \mu \mathrm{m}, n=5)$, centric. Periphyses: $1-2 \mu \mathrm{m}$ wide $(\mathrm{M}=1.5 \mu \mathrm{m}, n=20)$, hyaline, short. Peridium: two-layered; outer layer 5-7 $\mu \mathrm{m}(\mathrm{M}=5.5 \mu \mathrm{m}$, $n=10)$, dense, reddish-brown cells of textura angularis $8-15 \times 1-2 \mu \mathrm{m}(\mathrm{M}=10.8 \times 1.6 \mu \mathrm{m}$, $n=15)$, thick-walled. Inner layer: $7-12 \mu \mathrm{m}(\mathrm{M}=9.5 \mu \mathrm{m}, n=10)$, loosely arranged, hyaline cells of textura angularis 9.5-18 $\times 1-3 \mu \mathrm{m}(\mathrm{M}=12 \times 1.5 \mu \mathrm{m}, n=15)$, thin-walled, loosely arranged. Paraphyses: $2-4 \mu \mathrm{m}$ wide ( $\mathrm{M}=3 \mu \mathrm{m}, n=20)$, hyaline, highly delicate, cellular, constricted septate, guttulate; $1-2 \mu \mathrm{m}$ wide ( $\mathrm{M}=1.5 \mu \mathrm{m}, n=20)$, hyaline, filiform, longer than asci, blunt end, cellular, guttulate, embedded in a gelatinous matrix. Asci: $85-130 \times 5-8 \mu \mathrm{m}(\mathrm{M}=110 \times 6.5 \mu \mathrm{m}, n=25)$, 8-spored, unitunicate, cylindrical, thin-walled, short-pedunculate, apically rounded, with a J+, discoid apical ring. Ascospores: 12-17.5 $\times 4-5.5 \mu \mathrm{m}(\mathrm{M}=15 \times 5 \mu \mathrm{m}, n=40), 1 / \mathrm{w} 3.1$, uniseriate, oblong or narrowly fusiform, first hyaline, guttulate, turning yellow to yellowish-brown, with a median septum, slightly constricted at the septum, straight to slightly curved, smooth-walled. Asexual morph: Coelomycetous. Conidiomata: superficial on PDA, solitary or aggregated, globose, dark brown. Conidiophores: $24-40 \times 1-3 \mu \mathrm{m}(\mathrm{M}=31 \times 2 \mu \mathrm{m}, n=15)$, arising from peridium, septate, branched, thick-walled, light brown to hyaline. Setae: $60-92 \times 3.5-5 \mu \mathrm{m}(\mathrm{M}=76 \times 4.5 \mu \mathrm{m}$, 
$n=5$ ), septate, thick-walled, blunt end, brown to light brown. Conidiogenous cells: $7.5-14.5 \times$ 1.5-2.5 $\mu \mathrm{m}(\mathrm{M}=11.5 \times 2 \mu \mathrm{m}, n=15)$, elongated conical, thin-walled, hyaline, annellidic, guttulate. Conidia: $14.5-18 \times 1.5-2.5 \mu \mathrm{m}(\mathrm{M}=16 \times 2 \mu \mathrm{m}, n=25)$, elongate-fusiform, curved, smooth-walled, hyaline, guttulate.

Culture characteristics: colonies on PDA, reaching 16-17 mm diameter after one week at $25^{\circ} \mathrm{C}$, the colonies are flat, circular, dense, with a smooth surface, entire margin, and white to light brown. Media become pale brown; reverse light brown at center and dirty white edges.

Material examined: China, Sichuan Province, Chengdu, University of Electronic Science and Technology of China (UESTC) campus, on the wood of Camellia japonica (Theaceae), 30 September 2019, M.C. Samarakoon, SAMC254 (HKAS 107021, holotype; MFLU 20-0504, isotype); ex-type living culture MFLUCC 20-0122.

Notes: Our specimens have solitary and aggregated, immersed ascomata with two-layered peridium, unitunicate asci with $\mathrm{J}+$, a discoid apical ring, and brown ascospores similar to amphisphaeriaceous species. Amphisphaeria camelliae possesses 1-septate ascospores similar to A. uniseptata, but differs in having single or aggregated, globose to subglobose (vs. single, subglobose or applanate) ascomata, thin paraphyses ( 3.1 vs. $5 \mu \mathrm{m}$ ) and large ascospores (1/w $3.1 \mathrm{vs.} \mathrm{1/w} \mathrm{2.7).}$ In the phylogenetic analyses, our collection also clusters with $A$. uniseptata. Based on morphology and phylogeny, our collection is introduced as a novel species A. camelliae.

Amphisphaeria curvaticonidia Samarak., Promp. \& K.D. Hyde, sp. nov. Figures 5 and 6

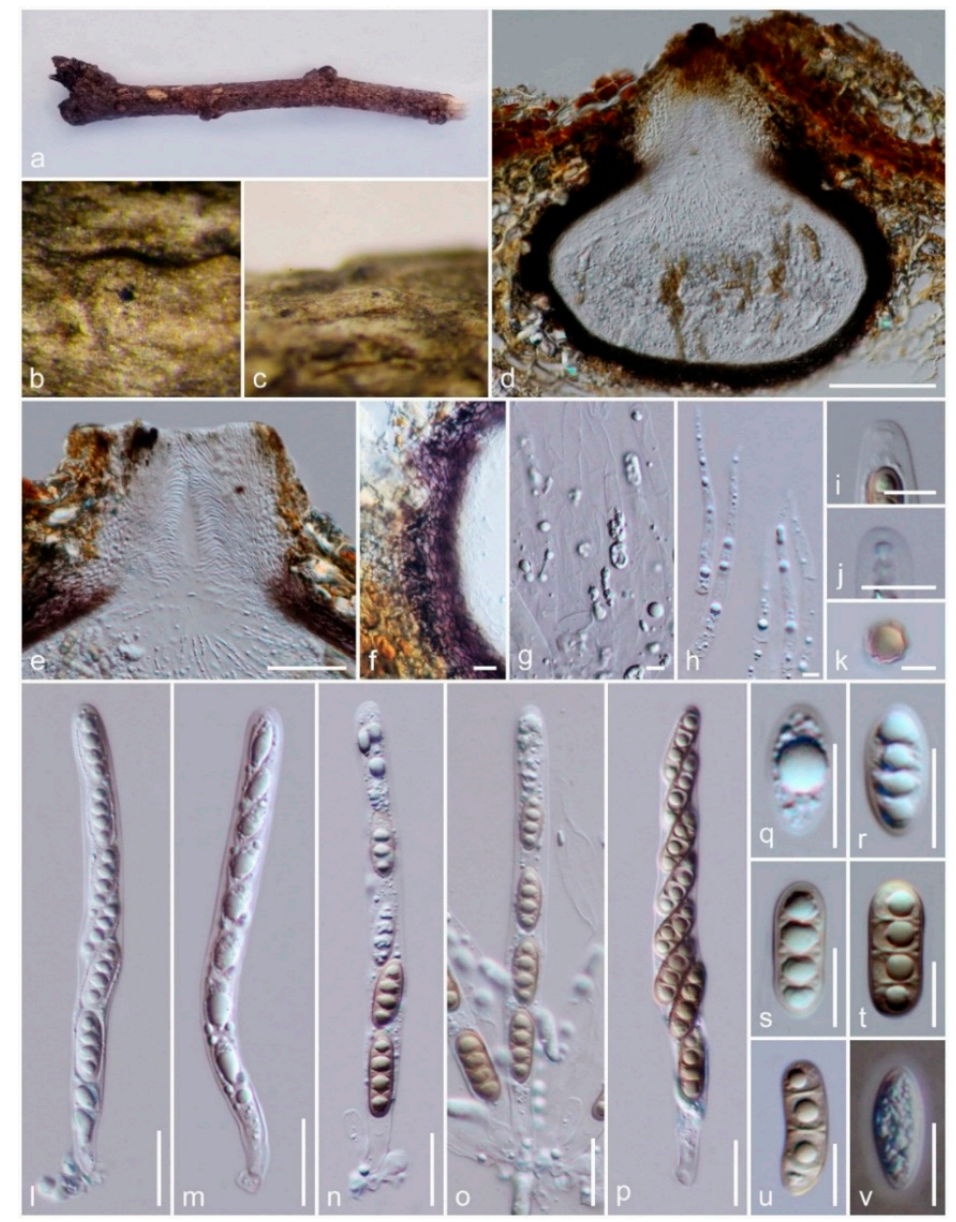

Figure 5. Sexual morph of Amphisphaeria curvaticonidia (MFLU18-0789, holotype). (a-c) Ascomata on the substrate; (d) vertical section of ascoma; (e) ostiole; (f) peridium; (g,h) paraphyses; (i) apical ring (in water); (j) apical ring bluing in Melzer's reagent; (k) ascospore (top view); (1-p) asci; (q-v) ascospores ( $\mathbf{v}$ in Indian Ink). Scale bars are set at, (d) $100 \mu \mathrm{m} ;(\mathbf{e}) 50 \mu \mathrm{m} ;(\mathbf{f}, \mathbf{l}-\mathbf{p}) 20 \mu \mathrm{m} ;(\mathbf{i}, \mathbf{j}, \mathbf{q}-\mathbf{v}) 10 \mu \mathrm{m} ;(\mathbf{g}, \mathbf{h}, \mathbf{k}) 5 \mu \mathrm{m}$. 


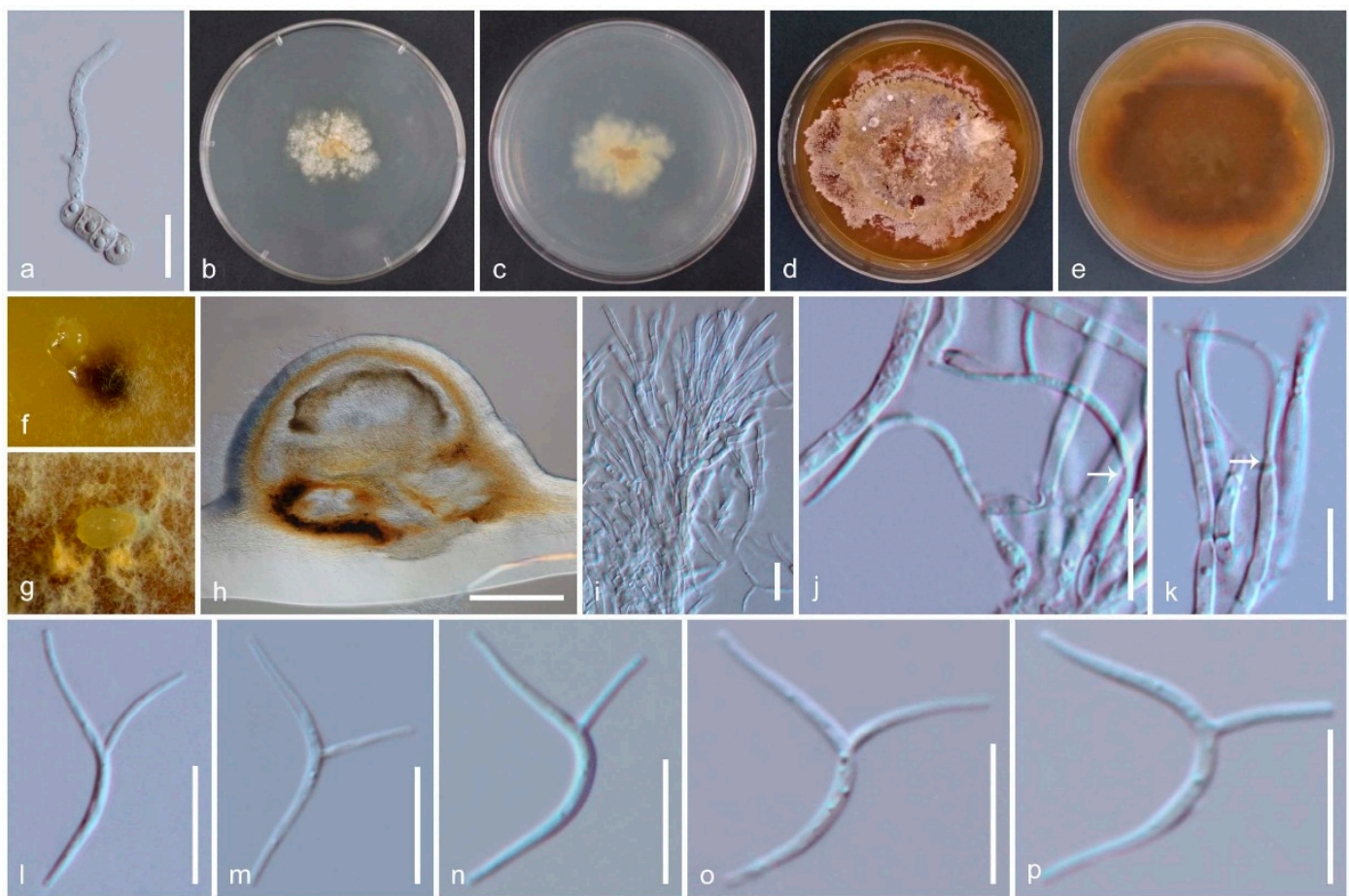

Figure 6. Asexual morph of Amphisphaeria curvaticonidia (MFLUCC 18-0620, ex-type living culture). (a) Germinating ascospore; (b) upper view, (c) reverse view of the 2 weeks old colony on PDA; (d) upper view, (e) reverse view of the 6 weeks old colony on PDA; (f,g) conidiomata in the culture; (h) vertical section of conidiomata in dried PDA; (i-k) conidiophores, conidiogenous cells, and conidiogenesis (white arrows show conidia attachment); (1-p) conidia. Scale bars are set at (h) $200 \mu \mathrm{m}$; (a) $20 \mu \mathrm{m} ;(\mathbf{i}-\mathbf{p}) 10 \mu \mathrm{m}$.

MycoBank: MB836111; Facesoffungi number: FoF08742

Etymology: The specific epithet curvaticonidia reflects the curved conidia.

Holotype: MFLU 18-0789

Saprobic on a dead branch. Sexual morph: Ascomata: 320-390 $\mu \mathrm{m}$ high $\times 360410 \mu \mathrm{m}$ diameter, $(\mathrm{M}=350 \times 385 \mu \mathrm{m}, n=8)$, immersed, visible as black spots, solitary, scattered, globose to subglobose or ovoid, papillate ostiole $75-140 \mu \mathrm{m}$ wide $(\mathrm{M}=110 \mu \mathrm{m}, n=5)$, yellowish-brown, centric. Periphyses: $1.5-3 \mu \mathrm{m}$ wide ( $\mathrm{M}=2.5 \mu \mathrm{m}, n=20)$, hyaline, short. Peridium: two-layered; outer layer: $18-26 \mu \mathrm{m}(\mathrm{M}=21 \mu \mathrm{m}$, $n=15)$, reddish-brown cells of textura angularis 7-21 $\times 1.5-4 \mu \mathrm{m}(\mathrm{M}=12 \times 2.5 \mu \mathrm{m}, n=20)$, thick-walled. Inner layer: $5.5-11 \mu \mathrm{m}(\mathrm{M}=8 \mu \mathrm{m}, n=15)$, hyaline cells of textura angularis $8-20 \times 1-2.5 \mu \mathrm{m}(\mathrm{M}=$ $12 \times 2 \mu \mathrm{m}, n=20)$, thin-walled, loosely arranged. Paraphyses: $3.5-5 \mu \mathrm{m}$ wide $(\mathrm{M}=4.5 \mu \mathrm{m}, n=20)$, hyaline, highly delicate, cellular, constricted septate, guttulate; 2-3.5 $\mu \mathrm{m}$ wide ( $\mathrm{M}=3 \mu \mathrm{m}, n=20)$, hyaline, filiform, longer than asci, blunt end, cellular, guttulate, embedded in a gelatinous matrix. Asci: $121-162 \times 10.5-17.5 \mu \mathrm{m}(\mathrm{M}=135 \times 12.5 \mu \mathrm{m}, n=25), 8$-spored, unitunicate, cylindrical, thin-walled, short-pedunculate, apically rounded, with a J+, discoid apical ring. Ascospores: $17-23 \times 6-9 \mu \mathrm{m}(\mathrm{M}=$ $20.5 \times 7.5 \mu \mathrm{m}, n=50), 1 / \mathrm{w} 2.7$, uniseriate, oblong or narrowly fusiform, first hyaline with a thin mucous sheath, turning yellow to yellow-brown, with 1 median, slightly constricted euseptum and two distosepta, straight to slightly curved, smooth-walled, with 8 longitudinal ridges which render the ascospore to appear octagonal in transverse section. Asexual morph: Coelomycetous. Conidiomata: 590-640 $\mu \mathrm{m}$ high $\times 370-490 \mu \mathrm{m}$ diam. $(\mathrm{M}=615 \times 425 \mu \mathrm{m}, n=3)$, immersed in PDA, solitary or aggregated, globose to sub-globose, dark brown. Peridium: comprised of thick-walled, septate, brown mycelium. Conidiophores: 11-17 $\times 1.5-2.5 \mu \mathrm{m}(\mathrm{M}=14 \times 2 \mu \mathrm{m}, n=15)$, septate, branched, thick-walled, hyaline to light brown. Conidiogenous cells: $7-17 \times 2-2.5 \mu \mathrm{m}(\mathrm{M}=12.5 \times 2.2 \mu \mathrm{m}, n=15)$, elongate, thin-walled, hyaline, annellidic, guttulate. Conidia: $23.5-30 \times 1-2 \mu \mathrm{m}(\mathrm{M}=26.5 \times 1.5 \mu \mathrm{m}, n=25)$, hyaline, cylindrical, curved, smooth-walled, 
appendage derived from the middle of the conidia cell, $6-10.5 \mu \mathrm{m}$ long $(\mathrm{M}=8.5 \mu \mathrm{m}, n=20)$, curved. Culture characteristics: Colonies on PDA, reaching 9-10 mm diameter after 2 weeks at $25^{\circ} \mathrm{C}$; colonies are flat, irregular, and dense, with immersed and superficial mycelia, with a rough surface, fimbriate margin, white to light brown becoming orange to dark brown, media becoming brown; reverse light brown at center with dirty white edges, later becoming yellowish-brown.

Material examined: Thailand, Chiang Rai, Thoeng, Ban Mae Loi Rai, on a dead branch, $19^{\circ} 54^{\prime} \mathrm{N} 100^{\circ} 06^{\prime} \mathrm{E}, 350 \mathrm{~m} \mathrm{msl}, 11$ September 2017, M.C. Samarakoon, SAMC040 (MFLU 18-0789, holotype; HKAS 102288, isotype); ex-type living culture MFLUCC 18-0620.

Notes: Our collection shares immersed, clypeate, globose to subglobose ascomata with inner hyaline and outer brown peridium, sepatate, flexuose paraphyses and ellipsoidal, brown ascospores typical for Amphisphaeria. The J+ discoid apical ring is similar to several other species, including A. flava described from Thailand. However, A. flava differs from our new collection in having a halo on the host surface around the ostiole and 1-septate ascospores. Amphisphaeria mangrovei differs from our strains with $\mathrm{J}-$ and an apical ring in asci. In addition, some of the immature ascospores are covered with a thin mucilaginous sheath as in A. flava, A. lusitanica, A. seriata, A. sorbi and A. vibratilis. In addition, our collection has 1 median, slightly constricted at the euseptum, and two distosepta which are characteristic to $A$. depressa. Wang et al. [2] re-examined the herbarium specimen of $A$. depressa and noted that this unusual distoseptate ascospores characteristic is not matched with the generic description. However, based on unituniate asci with J+, apical ring, Wang et al. [2] accepted this species in Amphisphaeriaceae. The asexual coelomycetous from the culture of our strain is similar to the only known asexual morph of $A$. sorbi by having septate, branched, hyaline conidiophores, elongated conical, thin-walled, septate, hyaline, annellidic conidiogenous cells, and elongate-fusiform, 1-celled, hyaline conidia. The asexual morph of our strain is characterized with curved appendage derived from the middle of the conidia cell. Here we introduce our new collection as A. curvaticonidia.

Amphisphaeria depressa Petr., Sydowia 7(5-6): 381 (1953)

MycoBank: MB292502; Facesoffungi number: FoF08743

Typus: USA, Hawaii, Kaihea, Oahu, on Cassia bicapsularis (Fabaceae), 24 Feb. 1928, Shear (W 11997, holotype; BPI 618577, isotype).

Notes: Wang et al. [2] re-examined the holotype and remarked the distoseptate ascospores are an unusual character of this species and accommodated in Amphisphaeria until further collections are made.

Amphisphaeria doidgeae Marinc., M.J. Wingf. \& Crous, in Marincowitz et al., CBS Diversity Ser. (Utrecht) 7: 20 (2008)

MycoBank: MB506197; Facesoffungi number: FoF08744

Typus: South Africa, Western Cape Province, Kleinmond, on twig litter of Leucadendron sp. (Proteaceae), 11 July 2000, S. Marincowitz, S.L. 485 (PREM 59556, holotype).

Notes: Amphisphaeria doidgeae is characterized by having broader peridium $(59-72 \mu \mathrm{m})$, septate and branched paraphyses, asci with a J- apical ring and broadly fusiform with a base often projected and truncate ascospores.

Amphisphaeria fallax De Not., Hedwigia 4: 21 (1865)

MycoBank: MB187770; Facesoffungi number: FoF08745

Typus: Czech Republic, Weißkirchen, on Quercus robur (Fagaceae), Apr. 1936, F. Petrak (DAOM 148328, neotype).

Notes: Wang et al. [2] designated a neotype by observing a slide collection from Quercus robur deposited by Petrak in 1936 with similar morphology.

Amphisphaeria flava Samarak. \& K.D. Hyde, Phytotaxa 391 (3): 210-211 (2019)

MycoBank: MB555396; Facesoffungi number: FoF04976

Typus: Thailand, Chiang Mai, Chang Wat, Amphoe Mae Taeng, Tambon Pa Pae, on a senescent branch, 01 September 2017, M.C. Samarakoon, SAMC019 (MFLU 18-0102, holotype; HKAS 102301, isotype); ex-type living culture MFLUCC 18-0361. 
Notes: Samarakoon et al. [7] introduced A. flava from Thailand which is easy to observe on the host with its round, pale yellow appearance around the ostiole.

Amphisphaeria fuckelii (G.H. Otth) Samarak., Maharachch. \& K.D. Hyde, comb. nov.

MycoBank: MB836119; Facesoffungi number: FoF08746

$\equiv$ Massaria fuckelii G.H. Otth, Mitth. Naturf. Ges. Bern Nr. 654-683: 50 (1868)

= Massaria fuckelii Fuckel, Jahrb. Nassauischen Vereins Naturk. 23-24: 155. 1870. [1869-70]

= Lepteutypa fuckelii (G.H. Otth) Petr., Ann. Mycol. 21: 276 (1923)

Typus: Belgium, Leuven, Heferlee, Heferleebos, on Tilia cordata (Malvaceae), 31 May 2012, P. Bormans (WU 33554, neotype); ex-type living culture CBS 140409.

Notes: Jaklitsch et al. [16] proposed a neotype for Lepteutypa fuckelii on Tilia cordata from Belgium (see the generic amendment above).

Amphisphaeria gaubae (Petr.) Y. Z. Wang, Aptroot \& K.D. Hyde, Fungal Diversity Res. Ser. 13: $13(2004)$

MycoBank: MB373366; Facesoffungi number: FoF08748

三 Didymosphaeria gaubae Petr., Sydowia 8: 195. (1954)

Typus: Australia, Australian Capital District, Jervis Bay, on dead leaves of Lambertia formosa (Proteaceae), 14 July 1950, Gauba (H, holotype).

Notes: Aptroot [64] transferred Didymosphaeria gaubae to Amphisphaeria and Wang et al. [2] re-examined the holotype and accepted the transfer to Amphisphaeria due to the combination of clypeate perithecia, unitunicate asci with J+ apical ring and 1-septate, slightly curved ascospores.

Amphisphaeria lusitanica (Niessl) Y. Z. Wang, Aptroot \& K.D. Hyde, Fungal Diversity Res. Ser. 13: 16 (2004)

MycoBank: MB373365; Facesoffungi number: FoF08751

$\equiv$ Phorcys lusitanica Niessl, Inst. Coimbra 31: 15 (1883)

$=$ Didymosphaeria lusitanica (Niessl) Berl. \& Voglino, in Saccardo, Syll. fung., Addit. I-IV (Abellini): $115(1886)$

= Microthelia lusitanica (Niessl) Kuntze, Revis. gen. pl. (Leipzig) 3(3): 498 (1898)

Typus: Portugal, Figueira da Foz, on Arundo donax (Poaceae), June 1880, Moller, 986 (M, holotype).

Notes: The wedge-shaped apical ring and ascospores strongly constricted at the septum have a close affinity to Arecophila in Cainiaceae [2].

Amphisphaeria mangrovei Devadatha \& V.V. Sarma, in Phookamsak et al., Fungal Diversity 95: 161 (2019)

MycoBank: MB554279; Facesoffungi number: FoF04273

Typus: India, Tamil Nadu, Tiruvarur, Muthupet mangroves, on intertidal branches and twigs of Suaeda monoica (Chenopodiaceae), 29 October 2016, B. Devadatha (AMH-9948 holotype); ex-type living culture NFCCI-4247.

Notes: Phookamsak et al. [6] introduced Amphisphaeria mangrovei on intertidal branches and twigs as the first report of Amphisphaeria species associated with mangrove habitats. LSU-SSU-ITS phylogenies revealed that $A$. mangrovei is a sister to A. sorbi.

Amphisphaeria micheliae Samarak., Jian K. Liu \& K.D. Hyde, sp. nov. Figure 7 


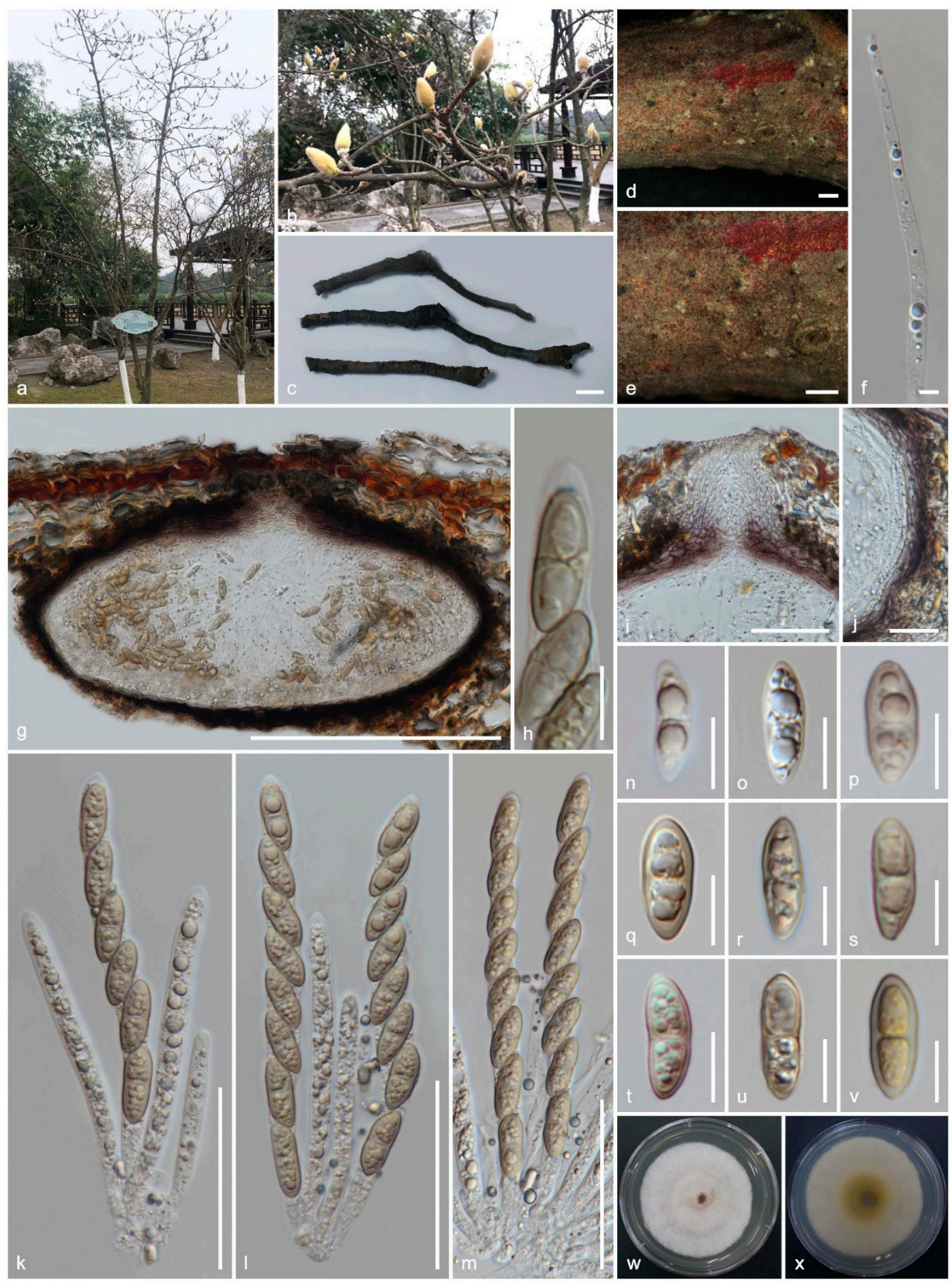

Figure 7. Sexual morph of Amphisphaeria micheliae (HKAS 107012, holotype). (a,b) Host Michelia alba; (c) substrate; (d,e) ascomata on the substrate; (f) paraphyses; (g) vertical section of ascoma; (h) apical ring bluing in Melzer's reagent; (i) ostiole; (j) peridium; (k-m) asci; $(\mathbf{n}-\mathbf{v})$ ascospores (v in Melzer's reagent); (w) upper view, (x) reverse view of the 2 weeks old colony on PDA. Scale bars are set at (c) 1 cm; (d,e) $500 \mu \mathrm{m} ;(\mathbf{g}) 200 \mu \mathrm{m} ;(\mathbf{i}, \mathbf{k}-\mathbf{m}) 50 \mu \mathrm{m} ;(\mathbf{j}) 20 \mu \mathrm{m} ;(\mathbf{h}, \mathbf{n}-\mathbf{v}) 10 \mu \mathrm{m}$.

MycoBank: MB836112; Facesoffungi number: FoF08752

Etymology: The specific epithet reflects the host genus Michelia.

Holotype: HKAS 107012 
Saprobic on a dead branch of Michelia alba. Sexual morph: Ascomata: 180-210 $\mu \mathrm{m}$ high $\times 225-370 \mu \mathrm{m}$ diameter $(\mathrm{M}=190 \times 300 \mu \mathrm{m}, n=8)$, immersed, visible as black spots in light coloured area on the host, solitary, scattered, subglobose to oblate, papillate ostiole 60-76 $\mu \mathrm{m}$ high $\times 34-50 \mu \mathrm{m}$ diam. $(\mathrm{M}=68 \times 42 \mu \mathrm{m}, n=8)$, centric. Periphyses: $1-2 \mu \mathrm{m}$ wide $(\mathrm{M}=1.5 \mu \mathrm{m}, n=20)$, hyaline, short. Peridium: two-layered; outer layer: $6.5-11.5 \mu \mathrm{m}(\mathrm{M}=8.5 \mu \mathrm{m}, n=10)$, dense, reddish brown cells of textura angularis $6.5-12.5 \times 1-2.5 \mu \mathrm{m}(\mathrm{M}=9 \times 1.5 \mu \mathrm{m}, n=15)$, thick-walled. Inner layer: $4-8 \mu \mathrm{m}(\mathrm{M}=6 \mu \mathrm{m}$, $n=10)$, loosely arranged, hyaline cells of textura angularis $10.5-17.5 \times 2.5-4 \mu \mathrm{m}(\mathrm{M}=14.5 \times 3 \mu \mathrm{m}, n=15)$, thin-walled, loosely arranged. Paraphyses: $3.5-4.5 \mu \mathrm{m}$ wide $(\mathrm{M}=4 \mu \mathrm{m}, n=20)$, hyaline, highly delicate, cellular, constricted septate, guttulate, embedded in a gelatinous matrix. Asci: $92-135 \times 7-10.5 \mu \mathrm{m}$ $(\mathrm{M}=115 \times 8.5 \mu \mathrm{m}, n=25), 8$-spored, unitunicate, cylindrical, thin-walled, short-pedunculate, apically rounded, with a J+, discoid apical ring. Ascospores: 15.5-21 $\times 6-7.5 \mu \mathrm{m}(\mathrm{M}=18 \times 6.5 \mu \mathrm{m}$, $n=40), 1 / w 2.7$, uniseriate, oblong or narrowly fusiform, first hyaline, guttulate, turning yellow to yellow-brown, 1-septate, slightly constricted at septum, straight to slightly curved, smooth-walled. Asexual morph: Undetermined.

Culture characteristics: colonies on PDA, reaching 20-22 mm diameter after one week at $25^{\circ} \mathrm{C}$; colonies are flat, circular, and dense, with a smooth surface, entire margin, concentrically zonate, white to light brown, media becoming pale brown; reverse yellowish brown at center and light brown edges.

Material examined: China, Sichuan Province, Chengdu, University of Electronic Science and Technology of China (UESTC) campus, on a dead branch of Michelia alba (Magnoliaceae), 30 September 2019, M.C. Samarakoon, SAMC244 (HKAS 107012, holotype; MFLU 20-0503, isotype); ex-type living culture MFLUCC 20-0121.

Notes: Two of our collections have solitary, immersed ascomata with two-layered peridium, unitunicate asci with $\mathrm{J+}$, discoid apical ring, and brown ascospores. This collection also has 1-septate ascospores similar to Amphisphaeria unisepta and A. camelliae. Compared to those two similar species, this collection has subglobose to oblate ascomata and oblong or narrowly fusiform ascospores. The phylogenetic analyses show MFLUCC 20-0121 and HKAS 107012 are closely related to A. sambuci, isolated from partly decorticated branches of Sambucus nigra. Amphisphaeria sambuci is different from our new collection in having large, depressed globose ascomata and oblong-ellipsoid, straight, rarely curved, 2-4(-6)-distoseptate ascospores with a thick mucilaginous sheath. Based on the morphology and phylogeny, here we introduce it as the novel species A. micheliae.

Amphisphaeria multipunctata (Fuckel) Petr., Annls mycol. 21(3/4): 329 (1923) (as "Amphisphaeria millepunctata")

MycoBank: MB271193; Facesoffungi number: FoF08753

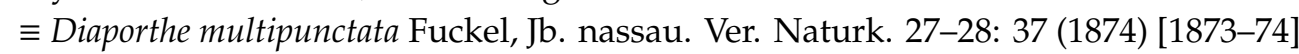

= Sphaeria acerina $($ Rehm) Cooke \& Plowr. (1833)

= Didymosphaeria acerina Rehm, Ascomyceten: no. 2237 (1874)

= Didymosphaeria acerina var. fraxini G. Winter ex Sacc., Syll. fung. (Abellini) 1: 714 (1882)

= Massariopsis acerina (Rehm) Kirschst., Annls mycol. 33(3/4): 218 (1935)

Typus: Switzerland, Neuchâtel, Ca. Neuchatel, on dry branches of Corylus avellana (Betulaceae), in spring, Morthier, Fuckel, Fungi Rhen. Exs. nr. 2661 (holotype?)

Notes: Aptroot [64] synonymized several Didymodphaeria species under Amphisphaeria multipunctata. Samuels et al. [65] noted that Petrak [10] has spelled as "Diaporthe millepunctata" erroneously and the Amphisphaeria multipunctata is the correct name. Aptroot [64] documented the host association of A. multipunctata as Acer campestre (Aceraceae), Carpinus betulus, Quercus robur (Fagaceae), Fraxinus excelsior, Syringa vulgaris (Oleaceae), Prunus spinosa, Sorbus aucuparia (Rosaceae), Rhus glabra (Anacardiaceae) and Viburnum opulus (Caprifoliaceae).

Amphisphaeria neoaquatica Samarak., Maharachch. \& K.D. Hyde, nom. nov.

MycoBank: MB836114; Facesoffungi number: FoF08737 
三Lepteutypa aquatica Z.L. Luo, K.D. Hyde \& H.Y. Su, in Luo et al., Fungal Diversity: 99:629 (2019) non-Amphisphaeria aquatica (Ellis \& Everh.) Berl. \& Voglino, in Saccardo, Syll. fung., Addit. I-IV (Abellini): 125 (1886); Amphisphaeria aquatica Plöttn. \& Kirschst., in Kirschstner, Verh. bot. Ver. Prov. Brandenb. 48: 52 (1906) [1907]

Typus: Thailand, Chiang Rai Province, on submerged decaying wood in a freshwater stream, Nov. 2013, K.D. Hyde, ZL-23 (MFLU 15-0077, holotype); ex-type living culture MFLUCC 14-0045.

Notes: Luo et al. [17] introduced Amphisphaeria aquatica (later re-named A. neoaquatica) which is similar to $A$. uniseptata by having subglobose, black, immersed ascomata and long cylindrical asci. ITS-LSU phylogeny shows that $A$. neoaquatica is basal to amphisphaeriaceous species [17].

Amphisphaeria paedida (Berk. \& Broome) Sacc., Syll. fung. (Abellini) 1: 724 (1882)

MycoBank: MB208832; Facesoffungi number: FoF08754

$\equiv$ Sphaeria paedida Berk. \& Broome, Ann. Mag. nat. Hist., Ser. 4 11: 348 (1873)

$=$ Conisphaeria paedida (Berk. \& Broome) Cooke, in Cooke \& Plowright, Grevillea 7(no. 43): 86 (1878)

= Melanomma paedida (Berk. \& Broome) Cooke (?)

Typus: United Kingdom, on Fagus sylvatica (Fagaceae), Apr. 1859 (K(M), holotype).

Notes: Wang et al. [2] re-examined a specimen of A. paedida and noted that the superficial ascomata, J- apical ring and ascospores with thickened septa are characteristic of the species. However, fresh collection and taxonomic revision is needed.

Amphisphaeria pakistanae E. Müll. \& S. Ahmad, Biologia, Lahore 3: 10 (1957)

MycoBank: MB292509; Facesoffungi number: FoF08755

Typus: Pakistan. Swat, Kalam, on dead branches of Indigofera sp. (Fabaceae), 18 Aug. 1952, S. Ahmad (Z+ZT 9032, holotype).

Notes: Amphisphaeria pakistanae has large ascomata and relatively small, light brown ascospores [2].

Amphisphaeria pseudoumbrina Sacc., Atti Soc. Veneto-Trent. Sci. Nat. 2(1): 112 (1873)

MycoBank: MB225907; Facesoffungi number: FoF08757

Typus: Italy, on the bark of Acer campestre (Sapindaceae) (VER, isotype).

Notes: Saccardo [66] described A. pseudoumbrina which has oblate ascomata, smaller asci and relatively broader ascospores compared to A. umbrina. Wang et al. [2] re-examined the isotype, which was found on Acer campestre in Italy, and accepted in Amphisphaeria.

Amphisphaeria qujingensis (Dissan., J.C. Kang \& K.D. Hyde) Samarak., Maharachch. \& K.D. Hyde, comb. nov.

MycoBank: MB836127; Facesoffungi number: FoF06506

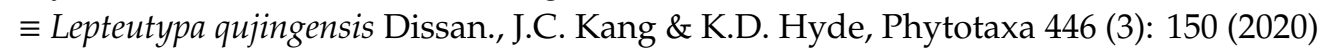

Typus: China, Yunnan Province, Qujing, on a senescent branch of an unknown host, 06 May 2019, L.S. Dissanayake, DW1137-045 (HMAS 290478, holotype; HKAS 107065, isotype); ex-type living culture KUMCC 19-0187.

Notes: Amphisphaeria qujingensis is similar in morphology to A. fuckelii in having immersed ascomata, J+ apical ring, and multiguttulate, hyaline to brown ascospores. LSU-ITS phylogenies also showed that $A$. qujingensis is sister to $A$. fuckelii with strong statistical support.

Amphisphaeria sambuci (Jaklitsch \& Voglmayr) Samarak., Maharachch. \& K.D. Hyde, comb. nov.

MycoBank: MB836129; Facesoffungi number: FoF08759

$\equiv$ Lepteutypa sambuci Jaklitsch \& Voglmayr, Persoonia 37: 88 (2016a)

Typus: England, Yorkshire, Worksop, Rotherham, Anston, Anstonstones Wood, on partly decorticated branches of Sambucus nigra (Adoxaceae), 16 May 2011, T. Læssøe et al. (WU 33556, holotype); ex-type living culture CBS 131707.

Notes: Jaklitsch et al. [16] introduced Amphisphaeria sambuci on mostly decorticated branches of Sambucus nigra lying on the ground and sometimes submerged in aquatic habitats from Europe. Amphisphaeria sambuci has immersed ascomata, asci with $\mathrm{J}+$, apical ring and ascospores with a central scarcely constricted euseptum and 2-4(-6)-distoseptate.

Amphisphaeria seriata M.E. Barr \& A.W. Ramaley, Mycotaxon 58: 350 (1996) 
MycoBank: MB414608; Facesoffungi number: FoF08760

Typus: USA, Texas, Enchanted rock state park, Gillespie Co., on leaf of Nolina sp. (Asparagaceae), 23 October 1993, A.W. Ramaley (BPI 802953, holotype).

Notes: The finely foveolate ascospores are reminiscent of Arecophila foveata, but this species differs by having a discoid apical ring [2]. Furthermore, Arecophila species are mainly from monocots and A. seriata needs to be re-collected and taxonomically revised.

Amphisphaeria sorbi Senan. \& K.D. Hyde, in Liu et al., Fungal Divers 71: 10 (2015)

MycoBank: MB550904; Facesoffungi number: FoF00414

Typus: Italy, Trento [TN], Dimaro, Folgarida, on the branch of Sorbus aucuparia (Rosaceae), 02 August 2013, E. Camporesi, IT 1400 (MFLU 14-0797, holotype); ex-type living culture MFLUCC 13-0721.

Notes: Liu et al. [5] introduced Amphisphaeria sorbi with its holomorph and LSU phylogeny from Italy. Amphisphaeria sorbi is highly similar to A. vibratilis but differs in having small perithecia, wide, non-flexuose paraphyses and smooth-walled ascospores without deeply pigmented septa.

Amphisphaeria thailandica Samarak. \& K.D. Hyde, Phytotaxa 391 (3): 210-211 (2019)

MycoBank: MB555397; Facesoffungi number: FoF04977

Typus: Thailand, Phayao, Phu Sang, Doi Phu Nang, on a dead branch, 20 July 2017, M.C. Samarakoon, SAMC097 (MFLU 18-0794, holotype; HKAS 102290, isotype).

Notes: Amphisphaeria thailandica is distinguished from other Amphisphaeria species by having subglobose to oval, hyaline bi-guttulate immature and light brown to greyish bi-guttulate ascospores, lacking a mucilaginous sheath.

Amphisphaeria uniseptata (C.K.M. Tsui, K.D. Hyde \& Hodgkiss) Samarak., Maharachch. \& K.D. Hyde, comb. nov.

MycoBank: MB836132; Facesoffungi number: FoF08763

三 Clypeosphaeria uniseptata C.K.M. Tsui, K.D. Hyde \& Hodgkiss, Mycologia 93(5): 1004 (2001)

= Lepteutypa uniseptata (C.K.M. Tsui, K.D. Hyde \& Hodgkiss) Jaklitsch \& Voglmayr, Persoonia 37: 88 (2016a)

Typus: Hong Kong, Tai Po, Lam Tsuen River, on submerged wood, Sept. 1997, R.M. Tsui, EjM 247 (HKU(M) 8095, holotype); ex-type living culture HKUCC 6579.

Notes: Tsui et al. [67] introduced Amphisphaeria uniseptata on submerged wood from Hong Kong and noted that it is similar to A. pakistanae in having ellipsoidal, brown, 1-sepatate but differs from having thick-walled ascospores. Jaklitsch et al. [16] placed this species in Lepteutypa emphasizing the presence of clypeus, long cylindrical asci with the J+ apical ring and uniseriate, ellipsoidal, brown ascospores.

Amphisphaeria vibratilis (Fuckel) E. Müll., in Müller \& von Arx, Beitr. Kryptfl. Schweiz 11(no. 2): 695 (1962)

MycoBank: MB326176; Facesoffungi number: FoF08764

$\equiv$ Massaria vibratilis Fuckel, Jb. nassau. Ver. Naturk. 23-24: 154 (1870) [1869-70]

= Massariella vibratilis (Fuckel) Sacc., Syll. fung. (Abellini) 1: 716 (1882)

= Phorcys vibratilis (Fuckel) J. Schröt., Kryptogamische Flora Schlesiens 3: 381 (1897)

= Massariella vibratilis var. mespili Pass., in Brunaud, Ann. Soc. Sci. nat. Char.-Marit. 25: 29 (1888)

Typus: Canada, British Columbia, on the stem of Prunus sp. (Rosaceae), June 1915, J. Macoun (DAOM, isotype).

Notes: Wang et al. [2] re-examined the isotype. Amphisphaeria vibratilis has asci with the J- apical ring and verrucose ascospores with a mucilaginous sheath.

Amphisphaeria yunnanensis Dissan., J.C. Kang \& K.D. Hyde, in Dissanayake et al. Phytotaxa 446 (3): 144-158 (2020)

MycoBank: MB556876; Facesoffungi number: FoF06505 
Typus: China, Yunnan Province, Qujing, on a dead branch of an unknown host, 06 May 2019, L.S. Dissanayake, DW1137-048 (HMAS 290476, holotype; HKAS 107066, isotype); ex-type living culture KUMCC 19-0188.

Notes: Amphisphaeria yunnanensis has ascomata with narrow and long ostioles, asci with the $\mathrm{J}$-apical ring and ascospores without a gelatinous sheath.

\subsubsection{Taxa Needing Further Revisions}

Ten species of Lepteutypa lack molecular data and asexual morphs. There are some "Lepteutypa" species that have been considered with pestaloid-like asexual morphs as mentioned in the relevant notes below and it is not possible to place them in Amphisphaeria. Therefore, these "lepteutypa-like" taxa need to be recollected, and sexual-asexual connections, molecular data, and generic affiliations established. We therefore do not treat them in Amphisphaeria sensu stricto.

Lepteutypa alpestris (Ellis \& Everh.) M.E. Barr, Mycotaxon 46: 56 (1993)

= Melanomma alpestre Ellis \& Everh., Proc. Acad. nat. Sci. Philad. 46(3): 328 (1894)

Typus: USA, Washington, Mt. Paddo, on dead twigs of Arctostaphylos nevadensis (Ericaceae), July 1886, W.N. Suksdorf, 268 (NY, holotype; Washington 342, isotype).

Notes: Ellis and Everhart [68] introduced Lepteutypa alpestris with the sexual morph. However, they noted that one perithecium contained stromatic nature. Barr [14] revisited the species and accepted it in "Lepteutypa" which is closely related to L. cupressi by having 3-septate ascospores covered with mucilaginous sheath and their sizes. However, L. cupressi has been accepted as Seiridium cupressi $[16,69]$.

Lepteutypa biseptata Petr., Sydowia 8 (1-6): 197 (1954)

Typus: Australia, New South Wales, on thin branches of Daviesia latifolia (Fabaceae), 16 February 1951, E. Gauba (holotype).

Notes: Petrak [12] introduced Lepteutypa biseptata from Australia which has clypeate like greyish-brown discoloration, perithecia single or aggregated (two perithecia), and 1-3-septate ascospores with a mucilaginous sheath.

Lepteutypa cisticola Ade, Bot. Jb. 142: 109 (1928)

Typus: Spain, Canary Island, Tenerif, Barranco Anadigo, on Cistus monspeliensis (Cistaceae), 27 May 1926, A. Ade (W, Lectotype).

Notes: Lepteutypa cisticola has 3-5 gregarious ascomata, asci with J+ apical ring and euseptate, with 3-septate (or occasionally two transverse and one oblique) ascospores [70]. Petrak [71] introduced Adea canariensis while suggesting it was possibly the anamorph of L. cisticola. However, Nag Raj and Kendrick [70] re-described Seiridium canariense (= Adea canariensis).

Lepteutypa fusispora Petr., Sydowia 7(5-6): 387 (1953)

Typus: USA, Hawaii, on thin branches of Wisteria sp. (Fabaceae), 14 January 1928, Volcano, Nr. 1131a (holotype).

Notes: Lepteutypa fusispora has more or less often aggregated (often paired) perithecia and 1-septate, straight or curved ascospores [11]. The author has noted that the specimen was young, and asci and ascospores often shrink, and Diaporthe seposita is often found on the same collection. Nag Raj and Kendrick [70] re-examined the type specimen and remarked that "L. fusispora" is not congeneric with A fuckelii based on the J+ asci and ascospores.

Lepteutypa hederae (Fuckel) Rappaz, Mycol. helv. 7(1): 160 (1995)

$\equiv$ Amphisphaeria hederae Fuckel, Jb. nassau. Ver. Naturk. 25-26: 304 (1871)

= Anthostoma hederae (Fuckel) Sacc., Syll. fung. (Abellini) 1: 301 (1882)

Typus: Switzerland, near Neuchatel, on dead, corticated branches of Hedera helix (Araliaceae), by xylotomy probably Viburnum sp. (Adoxaceae), Mar. 1867, P. Morthier (G00111726!; Herbier Fuckel 1894 ex Herb, holotype).

Notes: Rappaz [72] accommodated the species in Lepteutypa. Jaklitsch et al. [16] re-examined the holotype, which was reported in the protologue to grow on corticated branches of Hedera helix 
(but as revealed by xylotomy, the host is probably Viburnum sp.) from Switzerland. Lepteutypa hederae possesses consistently 3-septate ascospores, lacking a median euseptum and asci with a J- apical ring. Lepteutypa hexagonalis Goh \& K.D. Hyde, Mycol. Res. 101(1): 85 (1997)

Typus: Ecuador, Oriente, Napo Province, Rio Cuyabeno, Cuyabeno rainforest, on dead trunk of Pinanga sp. (Arecaceae), August 1993, K. D. Hyde (BRIP 23007, holotype).

Notes: Goh and Hyde [15] introduced Lepteutypa hexagonalis which is characterized by having single or in groups of two, deeply immersed ascomata with a distinct ostiole, cylindrical asci with a J+ apical ring and brown, 3-septate, ascospores with 6-7 longitudinal ridges.

Lepteutypa podocarpi (Butin) Aa, Sydowia 39: 1 (1987) [1986]

= Keissleriella podocarpi Butin, Sydowia 27(1-6): 273 (1975) [1973-1974]

Typus: Chile, La Unión, leaves of Podocarpus nubigenus (Podocarpaceae), 29 August 1968, H. Butin (holotype).

Notes: Lepteutypa podocarpi was introduced by Butin [73] from Podocarpus nubigenus in Chile. Based on similar ascospore septation and a pestaloid asexual morph, van der Aa [74] accepted this taxon in Lepteutypa.

Lepteutypa sabalicola (Ellis \& G. Martin) M.E. Barr, Mycotaxon 46: 57 (1993)

= Sphaeria sabalicola Ellis \& G. Martin, Am. Nat. 16: 810 (1882)

= Leptosphaeria sabalicola (Ellis \& G. Martin) Sacc., Syll. fung. (Abellini) 2: LVII (1883)

= Heptameria sabalicola (Ellis \& G. Martin) Cooke, Grevillea 18(no. 86): 32 (1889)

Typus: USA, Florida, on petioles of Serenoa serrulata (= Sabal serrulata, Arecaceae), Feb. 1881, Martin (holotype).

Notes: Barr [14] re-examined the type of the specimen on Serenoa serrulata from Florida. Ascomata are usually gregarious beneath a conspicuous blackened clypeus. Ascospores are verruculose under the narrow hyaline coating. Another collection from Florida on Aralia spinosa is identical in asci and ascospores, but the ascomata form beaks that protrude 330-449 beyond the blackened clypeus.

Lepteutypa tropicalis Dulym., Sivan., P.F. Cannon \& Peerally, in Dulymamode, Cannon \& Sivanesan, Mycol. Res. 105(2): 249 (2001)

Typus: Mauritius, Petrin, on dead basal leaves of Pandanus rigidifolius (Pandanaceae), 30 April 1996,

R. Dulymamode, P52 (mycol. herb. Univ. Mauritius, holotype; IMI 376738, isotype).

Notes: Dulymamode et al. [75] introduced Lepteutypa tropicalis on the adaxial surface of dead fallen leaf bases of Pandanus rigidifolius and P. palustris from Mauritius.

Lepteutypa ulmicola (Ellis \& Everh.) M.E. Barr, Mycotaxon 46: 57 (1993)

= Clypeosphaeria ulmicola Ellis \& Everh., Proc. Acad. nat. Sci. Philad. 45: 138 (1893)

Typus: Canada, Ontario, on dead branches of Ulmus sp. (Ulmaceae), April 1892, Dearness, 1776 (NY, holotype).

Notes: Ascospores of Lepteutypa ulmicola have one median septum and two distosepta with strongly pigmented and irregularly roughened walls.

\subsubsection{Hymenopleella}

Hymenopleella Munk, Dansk Bot. Ark. 15(no. 2): 89 (1953)

MycoBank: MB2416; Facesoffungi number: FoF08765

= Dyrithiopsis L. Cai et al., Mycologia 95: 912 (2003)

= Neotruncatella Hyang B. Lee \& T.T.T. Nguyen, Fungal Diversity 80: 198 (2016)

= Trochilispora V.P. Abreu, A.W.C. Rosado \& O.L. Pereira, Fungal Diversity: 96, 169 (2019)

Type species: Hymenopleella hippophaëicola Jaklitsch \& Voglmayr, Persoonia 37: 96 (2016)

MycoBank: MB814829; Facesoffungi number: FoF08766

Typus: Austria, Niederösterreich, Gerasdorf, Marchfeldkanalweg, on twigs of Hippophaë rhamnoides (Elaeagnaceae), 12 August 2012, W. Jaklitsch (WU 32027, epitype); ex-type living culture CBS 140410.

Notes: Hymenopleella is a sexual morph genus and sexual-asexual connection was confirmed through phylogeny by Liu et al. [39] while synonymizing Dyrithiopsis and Neotruncatella under 
Hymenopleella. Jaklitsch et al. [16] epitypified the type species, Hymenopleella hippophaëicola, while Liu et al. [39] emended the generic description and provided updated phylogeny.

Hymenopleella schefflerae (V.P. Abreu, A.W.C. Rosado \& O.L. Pereira) Samarak., Maharachch. \& K.D. Hyde, comb. nov.

MycoBank: MB836133; Facesoffungi number: FoF08767

$\equiv$ Trochilispora schefflerae V.P. Abreu, A.W.C. Rosado \& O.L. Pereira, in Hyde et al., Fungal Divers 96: 171-173 (2019)

Typus: Brazil, Minas Gerais, Paraopeba, Floresta Nacional de Paraopeba (FLONA-Paraopeba), on leaves of Schefflera morototoni (Araliaceae), 30 January 2016, V.P. Abreu \& O.L. Pereira (VIC 44384, holotype); ex-type living culture COAD 2371.

For description, see Hyde et al., Fungal Divers 96: 1-242 (2019)

Notes: A BLASTn search of ITS and LSU sequences of Trochilispora schefflerae (COAD 2371) are most similar to Hymenopleella (= Dyrithiopsis) (Sporocadaceae). The LSU-ITS-RPB2 phylogeny in this study also revealed that $T$. schefflerae clustered with Hymenopleella austroafricana (CPC 21940) with high statistical support. When the genus was introduced in Amphisphaeriaceae, the phylogeny lacked sufficient taxa selection, i.e., they used taxa in Bartaliniaceae, Discosiaceae, Pestalotiopsidaceae, and Robillardaceae which are now synonymized under Sporocadaceae [16]. In addition, the genera used in Amphisphaeriaceae are now accepted in Sporocadaceae (Monochaetia, Morinia) and Sordariomycetes genera incertae sedis (Ellurema) [39]. The phylogenetic study in Hyde et al. [20] showed that T. schefflerae is closely related to Hymenopleella hippophaeicola (CBS 140410). However, Trochilispora was introduced as a new genus with an uncertain phylogenetic position in Amphisphaeriaceae [20]. Trochilispora schefflerae was introduced based on acervular conidiomata, a 3-5-celled, thickened, brown peridium, small conidiophores, discrete, annellidic conidiogenous cells and fusiform, straight or slightly curved, 3-4-septate conidia with medium brown central cells and hyaline to subhyaline end cells with an apical cell with a tubular, filiform, single, eccentric, unbranched, aseptate appendage and basal cell without a basal appendage. However, the photo plate shows a coelomycetous conidiomata and similar morphology to Hymenopleella (see Hyde et al. [20], Liu et al. [39]). Trochilispora schefflerae and $H$. austroafricana possess discrete, annellidic conidiogenous cells $(3.5-11.5 \times 1.5-3 \mu \mathrm{m}$ vs. $4-11.5 \times$ $1.5-3 \mu \mathrm{m}$ ) and septate conidia (3-4-septate, $13-21 \times 3.5-5 \mu \mathrm{m}$ vs. $3-5$ mostly 4 -septate, $15.5-\times 4-5 \mu \mathrm{m}$ ). Conidia of Trochilispora schefflerae have longer apical appendages $(2.5-7.5 \mu \mathrm{m})$ compared to those of H. austroafricana $(1.5-4.5 \mu \mathrm{m})$. Moreover, the spores of T. schefflerae lack basal appendages, which may be present in H. austroafricana. Based on morphology and phylogeny, here we treat Trochilispora as a synonym of Hymenopleella and accordingly recombine T. schefflerae in Hymenopleella.

\section{Discussion}

Jaklitsch et al. [16] concluded that the taxonomy of Lepteutypa and related genera is still unclear. Our morpho-molecular study corroborated this fact and revealed that Lepteutypa is an ill-defined genus and cannot be clearly segregated from Amphisphaeria. Barr [76] provided a key for genera in Amphisphaeriaceae. Amphisphaeria and Lepteutypa are placed together with brown ascospores (end cells hyaline or lightly pigmented at times) and single or few ascomata beneath the clypeus. According to her concept, taxa with 1-septate, smooth-walled or ornamented ascospore bearing species were placed in Amphisphaeria, while 3-septate ascospores with brown terminal cells, lacking elongate appendages, distoseptate at times, a wall usually ornamented and surrounded by narrow mucilaginous sheath were placed in Lepteutypa. This means that the ascospore septation played a key role in distinguishing the two genera. Jaklitsch et al. [16] combined Clypeosphaeria unisepta with L. unisepta addressing the ascospores septation as an insignificant characteristic for generic delimitation. Samuels et al. [65] had previously mentioned that the number of septa in the ascospores is not taxonomically significant at the generic level.

Several other studies also show that intraspecific morphological variations are not sufficient for generic delimitation (e.g., Hirayama and Tanaka [77]; Jaklitsch et al. [78]; Hyde et al. [79]; 
Wijayawardene et al. [80]). Amphisphaeria and Lepteutypa species differ in eutypoid stromata and septation of ascospores in the protologues. However, we consider that these morphologies are not sufficient to distinguish these genera. Here, we synonymize Lepteutypa under Amphisphaeria.

Supplementary Materials: The following are available online at http://www.mdpi.com/2309-608X/6/3/174/s1. Figure S1: ML tree revealed by RAxML from an analysis of the LSU-ITS matrix of the Amphisphaeriaceae and selected families of Amphisphaeriales.

Author Contributions: Conceptualization, M.C.S., S.S.N.M., K.D.H. and M.S.; methodology, M.C.S., S.S.N.M. and K.D.H.; resources, K.D.H., J.-K.L. and I.P.; writing-original draft preparation, M.C.S.; writing-review and editing, S.S.N.M., K.D.H., M.S., J.-K.L. and I.P.; supervision, I.P. and K.D.H.; funding acquisition, K.D.H., J.-K.L. and I.P. All authors have read and agreed to the published version of the manuscript.

Funding: This research was funded by Thailand Research Fund (TRF), grant number RDG6130001 (Impact of climate change on fungal diversity and biogeography in the Greater Mekong Sub region) and High-end Foreign Expert Introduction Plan to Kunming Institute of Botany, granted by the Ministry of Science and Technology of the People's Republic of China, grant number G20190139006.

Acknowledgments: M.C.S. and I.P. acknowledge the Chiang Mai University and Graduate School of Chiang Mai University for support of this research work. M.C.S. thanks the Mushroom Research Foundation (MRF), Chiang Rai, Thailand and the international exchange program between the Chiang Mai University and the University of Electronic Science and Technology of China (UESTC). M.S. and K.D.H. would like to thank the Royal Golden Jubilee PhD Program under Thailand Research Fund (RGJ) and the German Academic Exchange Service (DAAD) for a joint TRF-DAAD (PPP 2017-2018) academic exchange Grant. Authors would like to thank Pawel Dzialak, Konstanze Bensch, Thilini Chethana Kandawatthe and Shaun Pennycook for their advice and supports during this study.

Conflicts of Interest: The authors declare no conflict of interest.

\section{References}

1. Cesati, V.; de Notaris, G. Schema di classificazione degli sferiacei italici aschigeri più o meno appartenenti al genere Sphaeria nell'antico significato attribuitoglda Persoon. Comment. Soc Crittogamia Ital. 1863, 1, 177-240.

2. Wang, Y.Z.; Aptroot, A.; Hyde, K.D. Revision of the Ascomycete Genus Amphisphaeria; Fungal Diversity Press: Hong Kong, China, 2004; ISBN 962-86765-5-5.

3. Senanayake, I.C.; Maharachchikumbura, S.S.N.; Hyde, K.D.; Bhat, J.D.; Jones, E.B.G.; McKenzie, E.H.C.; Dai, D.Q.; Daranagama, D.A.; Dayarathne, M.C.; Goonasekara, I.D.; et al. Towards unraveling relationships in Xylariomycetidae (Sordariomycetes). Fungal Divers. 2015, 73, 73-144. [CrossRef]

4. Marincowitz, S.; Gryzenhout, M.; Wingfield, M.J. New and rare coelomycetes with appendage-bearing conidia from Pondoland, South Africa. Mycotaxon 2010, 111, 309-322. [CrossRef]

5. Liu, J.K.; Hyde, K.D.; Jones, E.B.G.; Ariyawansa, H.A.; Bhat, D.J.; Boonmee, S.; Maharachchikumbura, S.S.N.; McKenzie, E.H.C.; Phookamsak, R.; Phukhamsakda, C.; et al. Fungal diversity notes 1-110: Taxonomic and phylogenetic contributions to fungal species. Fungal Divers. 2015, 72, 1-197. [CrossRef]

6. Phookamsak, R.; Hyde, K.D.; Jeewon, R.; Bhat, D.J.; Jones, E.B.G.; Maharachchikumbura, S.S.N.; Raspé, O.; Karunarathna, S.C.; Wanasinghe, D.N.; Hongsanan, S.; et al. Fungal diversity notes 929-1035: Taxonomic and phylogenetic contributions on genera and species of fungi. Fungal Divers. 2019, 95, 1-273. [CrossRef]

7. Samarakoon, M.C.; Jack Liu, J.-K.; Hyde, K.D.; Promputtha, I. Two new species of Amphisphaeria (Amphisphaeriaceae) from Northern Thailand. Phytotaxa 2019, 391, 207-217. [CrossRef]

8. Senanayake, I.C.; Lian, T.-T.; Mai, X.-M.; Camporesi, E.; Zeng, Y.-J.; Tian, S.-L.; Xie, N. Taxonomy and phylogeny of Amphisphaeria acericola sp. nov. from Italy. Phytotaxa 2019, 403, 285-292. [CrossRef]

9. Dissanayake, L.S.; Samarakoon, M.C.; Mortimer, P.E.; Lu, Y.-Z.; Li, Q.-R.; Hyde, K.D.; Kang, J.-C. Morpho-molecular characterization of two novel amphisphaeriaceous species from Yunnan, China. Phytotaxa 2020, 446, 144-158. [CrossRef]

10. Petrak, F. Mykologische Notizen VI. Ann. Mycol. 1923, 21, 182-335.

11. Petrak, F. Beiträge zur pilzflora von Hawaii. Sydowia 1953, 7, 381-409.

12. Petrak, F. Beiträge zur Pilzflora Australiens. Sydowia 1954, 8, 192-220.

13. Swart, H.J. The fungus causing cypress canker. Trans. Br. Mycol. Soc. 1973, 61, 71-82. [CrossRef]

14. Barr, M.E. Redisposition of some taxa described by J. B. Ellis. Mycotaxon 1993, 46, 45-76. 
15. Goh, T.-K.; Hyde, K.D. Lepteutypa hexagonalis sp. nov. from Pinanga sp. in Ecuador. Mycol. Res. 1997, 101, 85-88. [CrossRef]

16. Jaklitsch, W.M.; Gardiennet, A.; Voglmayr, H. Resolution of morphology-based taxonomic delusions: Acrocordiella, Basiseptospora, Blogiascospora, Clypeosphaeria, Hymenopleella, Lepteutypa, Pseudapiospora, Requienella, Seiridium and Strickeria. Persoonia 2016, 37, 82-105. [CrossRef]

17. Luo, Z.-L.; Hyde, K.D.; Liu, J.-K.; Maharachchikumbura, S.S.N.; Jeewon, R.; Bao, D.-F.; Bhat, D.J.; Lin, C.-G.; Li, W.-L.; Yang, J.; et al. Freshwater Sordariomycetes. Fungal Divers. 2019, 99, 451-660. [CrossRef]

18. Petrak, F. Mykologische Notizen VIII. Ann. Mycol. 1925, 23, 1-143.

19. Kirk, P.M.; Cannon, P.F.; Minter, D.W.; Stalpers, J.A. Ainsworth E Bisby's Dictionary of the Fungi, 10th ed.; CABI Publishing: Wallingford, UK, 2008; ISBN 978-0-85199-826-8.

20. Hyde, K.D.; Tennakoon, D.S.; Jeewon, R.; Bhat, D.J.; Maharachchikumbura, S.S.N.; Rossi, W.; Leonardi, M.; Lee, H.B.; Mun, H.Y.; Houbraken, J.; et al. Fungal diversity notes 1036-1150: Taxonomic and phylogenetic contributions on genera and species of fungal taxa. Fungal Divers. 2019, 96, 1-242. [CrossRef]

21. Samarakoon, M.C.; Thongbai, B.; Hyde, K.D.; Brönstrup, M.; Beutling, U.; Lambert, C.; Miller, A.N.; Liu, J.-K.; Promputtha, I.; Stadler, M. Elucidation of the life cycle of the endophytic genus Muscodor and its transfer to Induratia in Induratiaceae fam. nov., based on a polyphasic taxonomic approach. Fungal Divers. 2020, 101, 177-210. [CrossRef]

22. Chomnunti, P.; Hongsanan, S.; Aguirre-Hudson, B.; Tian, Q.; Peršoh, D.; Dhami, M.K.; Alias, A.S.; Xu, J.; Liu, X.; Stadler, M.; et al. The sooty moulds. Fungal Divers. 2014, 66, 1-36. [CrossRef]

23. Jayasiri, S.C.; Hyde, K.D.; Ariyawansa, H.A.; Bhat, J.; Buyck, B.; Cai, L.; Dai, Y.-C.; Abd-Elsalam, K.A.; Ertz, D.; Hidayat, I.; et al. The Faces of Fungi database: Fungal names linked with morphology, phylogeny and human impacts. Fungal Divers. 2015, 74, 3-18. [CrossRef]

24. White, T.J.; Bruns, T.; Lee, S.; Taylor, J. Amplification and direct sequencing of fungal ribosomal RNA genes for phylogenetics. In PCR Protocols; Elsevier: Amsterdam, The Netherlands, 1990; pp. 315-322.

25. Vilgalys, R.; Hester, M. Rapid genetic identification and mapping of enzymatically amplified ribosomal DNA from several Cryptococcus species. J. Bacteriol. 1990, 172, 4238-4246. [CrossRef] [PubMed]

26. Liu, Y.J.; Whelen, S.; Hall, B.D. Phylogenetic relationships among ascomycetes: Evidence from an RNA polymerase II subunit. Mol. Biol. Evol. 1999, 16, 1799-1808. [CrossRef]

27. O'Donnell, K.; Cigelnik, E. Two divergent intragenomic rDNA ITS2 types within a monophyletic lineage of the fungus Fusarium are nonorthologous. Mol. Phylogenet. Evol. 1997, 7, 103-116. [CrossRef] [PubMed]

28. Katoh, K.; Rozewicki, J.; Yamada, K.D. MAFFT online service: Multiple sequence alignment, interactive sequence choice and visualization. Brief. Bioinform. 2019, 20, 1160-1166. [CrossRef]

29. Hall, T.A. BioEdit: A user-friendly biological sequence alignment editor and analysis program for Windows 95/98/NT. Nucleic Acids Symp. Ser. 1999, 41, 95-98.

30. Nylander, J.A.A. MrModeltest v2. Program Distributed by the Author; Evolutionary Biology Centre, Uppsala University: Uppsala, Sweden, 2004.

31. Swofford, D.L. PAUP* Version 4.0 b10. Phylogenetic Analysis Using Parsimony (* and Other Methods); Sinauer Associates: Sunderland, UK, 2002.

32. Kishino, H.; Hasegawa, M. Evaluation of the maximum likelihood estimate of the evolutionary tree topologies from DNA sequence data, and the branching order in Hominoidea. J. Mol. Evol. 1989, 29, 170-179. [CrossRef]

33. Miller, M.A.; Pfeiffer, W.; Schwartz, T. Creating the CIPRES Science Gateway for inference of large phylogenetic trees. In Proceedings of the 2010 Gateway Computing Environments Workshop (GCE), New Orleans, LA, USA, 14 November 2010; IEEE: Piscataway, NJ, USA; pp. 1-8.

34. Stamatakis, A. RAxML version 8: A tool for phylogenetic analysis and post-analysis of large phylogenies. Bioinformatics 2014, 30, 1312-1313. [CrossRef]

35. Huelsenbeck, J.P.; Ronquist, F. MRBAYES: Bayesian inference of phylogenetic trees. Bioinformatics 2001, 17, 754-755. [CrossRef]

36. Zhaxybayeva, O.; Gogarten, J.P. Bootstrap, Bayesian probability and maximum likelihood mapping: Exploring new tools for comparative genome analyses. BMC Genom. 2002, 3, 4. [CrossRef]

37. Rambaut, A. FigTree v. 1.4.0. Available online: http://tree.bio.ed.ac.uk/\%0Asoftware/figtree/ (accessed on 15 August 2020). 
38. Wang, X.W.; Houbraken, J.; Groenewald, J.Z.; Meijer, M.; Andersen, B.; Nielsen, K.F.; Crous, P.W.; Samson, R.A. Diversity and taxonomy of Chaetomium and chaetomium-like fungi from indoor environments. Stud. Mycol. 2016, 84, 145-224. [CrossRef]

39. Liu, F.; Bonthond, G.; Groenewald, J.Z.; Cai, L.; Crous, P.W. Sporocadaceae, a family of coelomycetous fungi with appendage-bearing conidia. Stud. Mycol. 2019, 92, 287-415. [CrossRef] [PubMed]

40. Schoch, C.L.; Sung, G.-H.; López-Giráldez, F.; Townsend, J.P.; Miadlikowska, J.; Hofstetter, V.; Robbertse, B.; Matheny, P.B.; Kauff, F.; Wang, Z.; et al. The Ascomycota tree of life: A phylum-wide phylogeny clarifies the origin and evolution of fundamental reproductive and ecological traits. Syst. Biol. 2009, 58, 224-239. [CrossRef] [PubMed]

41. Crous, P.W.; Shivas, R.G.; Quaedvlieg, W.; van der Bank, M.; Zhang, Y.; Summerell, B.A.; Guarro, J.; Wingfield, M.J.; Wood, A.R.; Alfenas, A.C.; et al. Fungal Planet description sheets: 214-280. Persoonia 2014, 32, 184-306. [CrossRef] [PubMed]

42. Crous, P.W.; Wingfield, M.J.; Guarro, J.; Cheewangkoon, R.; van der Bank, M.; Swart, W.J.; Stchigel, A.M.; Cano-Lira, J.F.; Roux, J.; Madrid, H.; et al. Fungal Planet description sheets: 154-213. Persoonia 2013, 31, 188-296. [CrossRef] [PubMed]

43. Cheewangkoon, R.; Groenewald, J.Z.; Summerell, B.A.; Hyde, K.D.; To-anun, C.; Crous, P.W. Myrtaceae, a cache of fungal biodiversity. Persoonia 2009, 23, 55-85. [CrossRef] [PubMed]

44. Vu, D.; Groenewald, M.; de Vries, M.; Gehrmann, T.; Stielow, B.; Eberhardt, U.; Al-Hatmi, A.; Groenewald, J.Z.; Cardinali, G.; Houbraken, J.; et al. Large-scale generation and analysis of filamentous fungal DNA barcodes boosts coverage for kingdom fungi and reveals thresholds for fungal species and higher taxon delimitation. Stud. Mycol. 2019, 92, 135-154. [CrossRef]

45. Crous, P.W.; Wingfield, M.J.; Guarro, J.; Hernández-Restrepo, M.; Sutton, D.A.; Acharya, K.; Barber, P.A.; Boekhout, T.; Dimitrov, R.A.; Dueñas, M.; et al. Fungal Planet description sheets: 320-370. Persoonia 2015, 34, 167-266. [CrossRef]

46. Lin, C.-G.; Bhat, D.J.; Liu, J.-K.; Hyde, K.D.; Wang, Y. The genus Castanediella. MycoKeys 2019, 51, 1-14. [CrossRef]

47. Giraldo, A.; Crous, P.W.; Schumacher, R.K.; Cheewangkoon, R.; Ghobad-Nejhad, M.; Langer, E. The Genera of Fungi-G3: Aleurocystis, Blastacervulus, Clypeophysalospora, Licrostroma, Neohendersonia and Spumatoria. Mycol. Prog. 2017, 16, 325-348. [CrossRef]

48. Crous, P.W.; Wingfield, M.J.; Schumacher, R.K.; Akulov, A.; Bulgakov, T.S.; Carnegie, A.J.; Jurjević, Ž.; Decock, C.; Denman, S.; Lombard, L.; et al. New and Interesting Fungi. 3. Fungal Syst. Evol. 2020, 6, 157-231. [CrossRef] [PubMed]

49. Crous, P.W.; Carnegie, A.J.; Wingfield, M.J.; Sharma, R.; Mughini, G.; Noordeloos, M.E.; Santini, A.; Shouche, Y.S.; Bezerra, J.D.P.; Dima, B.; et al. Fungal Planet description sheets: 868-950. Persoonia 2019, 42, 291-473. [CrossRef] [PubMed]

50. Crous, P.W.; Wingfield, M.J.; Schumacher, R.K.; Summerell, B.A.; Giraldo, A.; Gené, J.; Guarro, J.; Wanasinghe, D.N.; Hyde, K.D.; Camporesi, E.; et al. Fungal Planet description sheets: 281-319. Persoonia 2014, 33, 212-289. [CrossRef] [PubMed]

51. Crous, P.W.; Summerell, B.A.; Shivas, R.G.; Romberg, M.; Mel'nik, V.A.; Verkley, G.J.M.; Groenewald, J.Z. Fungal Planet description sheets: 92-106. Persoonia 2011, 27, 130-162. [CrossRef]

52. Quaedvlieg, W.; Verkley, G.J.M.; Shin, H.-D.; Barreto, R.W.; Alfenas, A.C.; Swart, W.J.; Groenewald, J.Z.; Crous, P.W. Sizing up Septoria. Stud. Mycol. 2013, 75, 307-390. [CrossRef]

53. Summerell, B.A.; Groenewald, J.Z.; Carnegie, A.J.; Summerbell, R.C.; Crous, P. Eucalyptus microfungi known from culture. 2. Alysidiella, Fusculina and Phlogicylindrium genera nova, with notes on some other poorly known taxa. Fungal Divers. 2006, 23, 323-350.

54. Crous, P.W.; Carris, L.M.; Giraldo, A.; Groenewald, J.Z.; Hawksworth, D.L.; Hemández-Restrepo, M.; Jaklitsch, W.M.; Lebrun, M.-H.; Schumacher, R.K.; Stielow, J.B.; et al. The Genera of Fungi-Fixing the application of the type species of generic names-G2: Allantophomopsis, Latorua, Macrodiplodiopsis, Macrohilum, Milospium, Protostegia, Pyricularia, Robillarda, Rotula, Septoriella, Torula, and Wojnowicia. IMA Fungus 2015, 6, 163-198. [CrossRef]

55. Bonthond, G.; Sandoval-Denis, M.; Groenewald, J.Z.; Crous, P.W. Seiridium (Sporocadaceae): An important genus of plant pathogenic fungi. Persoonia 2018, 40, 96-118. [CrossRef] [PubMed] 
56. Tang, A.M.C.; Jeewon, R.; Hyde, K.D. Phylogenetic utility of protein (RPB2, $\beta$-tubulin) and ribosomal (LSU, SSU) gene sequences in the systematics of Sordariomycetes (Ascomycota, Fungi). Antonie Leeuwenhoek 2007, 91, 327-349. [CrossRef]

57. Fries, E.M. Systema Mycologicum: Sistens Fungorum Ordines, Genera et Species, huc Usque Cognitas, Quas ad Normam Methodi Naturalis Determinavit/Disposuit Atque Descripsit Elias Fries; Ex Officina Berlingiana: Lund, Sweden, 2018; Volume 2, p. 1823.

58. Clements, F.E.; Shear, C.L. The Genera of Fungi; Wilson: New York, NY, USA, 1931.

59. Müller, E.; von Arx, J.A. Die Gattungen der didymosporen Pyrenomyceten. Beiträge Kryptogamenflora Schweiz $1962,11,1-922$.

60. Korf, R.P. Report (N.S. 1) of the Committee for Fungi and Lichens on proposals to conserve and/or reject names. Taxon 1988, 37, 450-463. [CrossRef]

61. Hyde, K.D.; Kang, J.C.; Kong, R.Y.C. Fungi from palms. XXX. Notes on Amphisphaeria species described from palms and a description of A. umbrina. Nov. Hedwig. 1996, 63, 101-108.

62. Saccardo, P.A.; Traverso, G.B.; Trotter, A. Sylloge Fungorum Omnium Hucusque Cognitorum. Digessit P. A. Saccardo; Sumptibus Auctoris: Patavi, Padova, Italy, 1882.

63. Ridley, G.S.; Dobbie, K.; Dick, M.A. Mycological records. 5: Lepteutypa podocarpi (Butin) van der Aa. N. Z. J. For. Sci. 1997, 27, 76-78.

64. Aptroot, A. Redisposition of some species excluded from Didymosphaeria (Ascomycotina). Nov. Hedwig. 1995, 60, 325-379.

65. Samuels, G.J.; Müller, E.; Petrini, O. Studies in the Amphisphaeriaceae (sensu lato) 3. New species of Monographella and Pestalosphaeria, and two new genera. Mycotaxon 1987, 28, 473-499.

66. Saccardo, P.A. Fungi Veneti novi vel critici. Series I. Nuovo G. Bot. Ital. 1873, 5, 269-298.

67. Tsui, C.K.M.; Hyde, K.D.; Hodgkiss, I.J. Paraniesslia tuberculata gen. et sp. nov., and new records or species of Clypeosphaeria, Leptosphaeria and Astrosphaeriella in Hong Kong Freshwater Habitats. Mycologia 2001, 93, 1002-1009. [CrossRef]

68. Ellis, J.B.; Everhart, B.M. New species of fungi from various localities. Proc. Acad. Nat. Sci. Phila. 1894, 46, 322-384.

69. Marin-Felix, Y.; Hernández-Restrepo, M.; Iturrieta-González, I.; García, D.; Gené, J.; Groenewald, J.Z.; Cai, L.; Chen, Q.; Quaedvlieg, W.; Schumacher, R.K.; et al. Genera of phytopathogenic fungi: GOPHY 3. Stud. Mycol. 2019, 94, 1-124. [CrossRef]

70. Nag Raj, T.R.; Kendrick, B. Ellurema gen. nov., with notes on Lepteutypa cisticola and Seiridium canariense. Sydowia Ann. Mycol. Ser. II 1985, 38, 178-193.

71. Petrak, F. Mykologische Beiträge zur Flora der kanarischen Inseln. Bot. Engler's Jahrb. Syst. Beibl. 1929, 142, 93-160.

72. Rappaz, F. Anthostomella and related xylariaceous fungi on hardwoord from Europe and North America. Mycol. Helv. 1995, 7, 99-168.

73. Butin, H. Beitrag zur Ascomyceten Flora von Chile. Sydowia 1973, 27, 267-292.

74. van der Aa, H.A. Revision of Keissleriella podocarpi BUTIN. Sydowia 1986, 39, 1-7.

75. Dulymamode, R.; Cannon, P.F.; Sivanesan, A.; Peerally, A. Fungi from Mauritius: Four new ascomycetes on native plants. Mycol. Res. 2001, 105, 247-254. [CrossRef]

76. Barr, M.E. Notes on the Amphisphaeriaceae and related families. Mycotaxon 1994, 51, 191-224.

77. Hirayama, K.; Tanaka, K. Taxonomic revision of Lophiostoma and Lophiotrema based on reevaluation of morphological characters and molecular analyses. Mycoscience 2011, 52, 401-412. [CrossRef]

78. Jaklitsch, W.M.; Olariaga, I.; Voglmayr, H. Teichospora and the Teichosporaceae. Mycol. Prog. 2016, 15, 31. [CrossRef]

79. Hyde, K.D.; Norphanphoun, C.; Maharachchikumbura, S.S.N.; Bhat, D.J. Refined families of Sordariomycetes. Mycosphere 2020, 11, 305-1059. [CrossRef]

80. Wijayawardene, N.N.; Hyde, K.D.; Al-Ani, L.K.T.; Tedersoo, L. Outline of Fungi and fungus-like taxa. Mycosphere 2020, 11, 1060-1456. [CrossRef]

(C) 2020 by the authors. Licensee MDPI, Basel, Switzerland. This article is an open access article distributed under the terms and conditions of the Creative Commons Attribution (CC BY) license (http://creativecommons.org/licenses/by/4.0/). 